\title{
Sünnî-Şiî İkilemine Farklı Bir Bakış: Yeniden İnşa Edilen Hadis Bağlamları*
}

\author{
Muhammed Enes Topgül**
}

\begin{abstract}
Şiî cemaatlerin hicrî ilk üç asır boyunca İslâm toplumunun ana bünyesini teşkil eden ehl-i hadisten ayrışma ve mezhepleşme sürecinde yaşananlar sadece bir dinî yapının kimlik bulma süreciyle değil aynı zamanda Sünnî hadis tarihi ile de pek çok açıdan ilgilidir. $\mathrm{Bu}$ çalışma bir açıdan Sünnî-Şiî rivayet geçişkenliklerine dair birtakım yargılarda bulunsa da temelde rivayet geçişleri esnasında vuku bulan bağlam değişimlerini tespit etmeyi hedeflemektedir. Bu tespit, uydurma faaliyetleri ve meşru bir zemini bulunmayan tevil çabaları kadar olmasa da yeniden inşa edilen hadis bağlamlarının mezhebî kabulleri desteklemedeki rolü hakkında fikir verecektir. Bağlam değişimleri birden fazla surette gerçekleşmektedir. Öncelikle bir kaynaktaki rivayet, farklı bir kaynakta bambaşka bir arka plan bilgisiyle sunulabilmekte, uzun bir rivayetin bir kısmı ayrıştırılarak bir veya aynı anlatının içerisine yerleştirilen birden fazla rivayetle yan yana anılabilmekte veya aynı bağlamla aktarılsa da kendisine yüklenen yeni anlam dolayısıyla aslî kastından uzaklaşabilmektedir. Özellikle fezâil ve mesâlib türü rivayetler ile polemik türü anlatılar bu takibi yapmak açısından hayli işlevseldir. Mezkûr geçişkenliği temin eden ve büyük oranda Şiî eğilimlere sahip olmakla itham edilen râvilerin belirlenmesi ise Şiî cemaatlerin ehl-i hadisten bağımsız olarak ilim yapma becerisini kazanma dönemlerine ışık tutabilir.
\end{abstract}

Anahtar kelimeler: Sünnî, Şiî, bağlam, Hz. Ali, hadis.

\section{Giriş}

Hadis rivayetinin hicrî ilk üç asırdaki tarihi incelenirken dikkate alınması gereken en önemli hususlardan biri hiç şüphesiz farklı dinî grupların sahip olduğu inanışların hadis rivayetlerine ne oranda ve hangi şekillerde etki ettiğidir. İlk iki asırdaki marjinal cemaat yapıları çoğu zaman müesses mezhepler olarak görülemese de, onların bulundukları konumu meşru

* Bu çalışma TÜBİTAK tarafından desteklenen 116K689 numaralı proje kapsamında kaleme alınmıştır.

** Ar.Gör.Dr., Marmara Üniversitesi İlahiyat Fakültesi Hadis Anabilim Dalı. ORCİD oooo-0003-3077-2610 enes.topgul@marmara.edu.tr 
kılmak adına birtakım hadis uydurma faaliyetlerine az veya çok iştirak ettikleri bir gerçektir. Zira dinî temelden mahrum bazı kabuller, müntesiplerini Kur'ân-1 Kerim âyetlerini ait olmadıkları bağlamlarda yorumlamaya veya Hz. Peygamber'in otoritesine başvurma gayesiyle muayyen konularda hadis uydurmaya sevketmiştir. Kabullerini dinin asıl metinleri üzerinden meşru kılmak her bir mezhebin başvurduğu bir yöntem olsa da buradaki faaliyetin ilmî sınırları belli bir tevil mekanizması çerçevesinde ortaya konulması ile genellikle "suskun olan" âyet ve hadislerin tamamen bağlamsızlaştırılarak yani hitap-muhatap gerçekliğinden soyutlanarak yeni durumlar için konuşturulması arasında ciddi bir farkın olduğu açıktır. ${ }^{1} \mathrm{Hem}$ dilin gramatik yapısıyla hem de tarihî gerçeklik ve tecrübeyle örtüşmeyen, dolayısıyla sınırları belli olmayan bir tevil faaliyeti de özellikle bir meşruiyet aracı olarak hadis uydurulması kadar etraflıca ele alınması gereken bir problemdir. Bu makalenin temel amacı, hadisin bir sahâbî, tâbiî ya da sonraki tabakadan biri tarafından nakledilme bağlamını ifade eden irat ${ }^{2}$ ve büyük oranda da musannif bağlamları ile eş zamanlı görünen ve Sünnî-Şiî etkileşimi ile ortaya çıkan, ayrıca bir yönüyle uydurma diğer bir yönüyle de tevil faaliyetleri kapsamına giren "bağlam inşası" problemini ele almaktır.

Genel olarak dilsel, sınıflandırıcı, konusal, işlevsel, varoluşsal, tarihsel ve toplumsal gibi tasniflere tâbi tutulan bağlam kavrami ${ }^{3}$ bu çalışmada büyük oranda hadislerin vürut sebepleri çerçevesinde kullanılacaktır. "Bağlam inşası" ya da "yeni/den inşa edilen bağlam" tabirleriyle ise konuşmanın ilk gerçekleştiği andaki tarihî çerçevenin hazfedilerek ilgili sözün/hadisin bir hâdise, fikir veya tepki etrafında yeni ve işlevsel bir anlatı içerisine yerleştirilmesi kastedilecektir. Yukarıda değinildiği üzere genellikle hadisin nakli veya bir esere kaydedilmesi aşamasında gerçekleşen bu durumun, sonuçları dikkate alınarak bir tür anlam kayması olarak görülmesi de mümkündür. Hadisler açısından düşünüldüğünde bir hadisin söylenme sebebini dikkate almadan yapılan ve zaman zaman aslî anlamı kaybedecek derecede hatalı olabilen taktî‘ ve ihtisar faaliyetleri, her hâlükârda gerçek anlamın tespitinde ciddi bir sorun teşkil eder. Burada ele alınacak bağlam inşasının ise şu

1 Burada akla ister istemez pek çok fikhî mezhep tarafından genel olarak kabul gören, "Sebeplerin hususiliği hükmün umumiliğine engel değildir" ilkesi gelse de kastedilen husus özellikle marjinal itikadî fırkaların dinî metinleri yorumlama mantığıdır.

2 İrat bilgisinin büyük oranda sahâbe ve tâbiîn tabakasındaki nakil sebepleriyle ilgili olduğu genel kabul görse de, rivayet mantığının sistemleşmesinin ardından da sebebe binaen yapılan nakillerle karşılaşılmaktadır. Bundan dolayı burada çerçeve daha geniş tutulmuş̧ur.

3 İlgili bağlam türleri ve hadisleri anlamaya yönelik muhtemel katkıları için bk. Görmez, Metodoloji Sorunu, s. 355 vd. 
üç surette meydana geldiği söylenebilir: 1. Bir kaynakta yer alan bir rivayet, farklı bir kaynakta bambaşka bir arka plan bilgisiyle sunulur (inşa/vazedilen bağlam). 2. Uzun bir rivayetin bir kısmı ayrıştırılarak bir veya aynı anlatının içerisine yerleştirilen birden fazla rivayetle yan yana anılır (farklılaşan bă̆lam). 3. Rivayet aynı bağlamla aktarılsa da kendisine yüklenen yeni anlam dolayısıyla aslî kastından uzaklaşır.

Erken İslâm tarihinde bağlam inşası/değişimi probleminin kontrolsüz tevil mekanizması ve hadis uydurmacıllğ 1 kadar olmasa da klasik kaynaklarda tesadüf edilen bir olgu olduğunu Sünnî ve Şiî eserlerdeki bazı rivayetler üzerinden göstermeyi hedefleyen bu makalede, mezkûr faaliyetin dönemi, coğrafyası ve sorumluları, Sünnî-Şiî rivayet geçişkenlikleri, iki ekolün ilim halkalarının ayrışma süreci ve Şiî itikadının gelişim evreleri hakkında birtakım yargılara varılmaya çalışılacaktır. Her hâlükârda bağlam inşasının mahiyeti ve kendisine müdahale edilen rivayetlerin itikadî kabulleri destekleme yönleri de bu çalışmanın konusudur. Sünnî ilim halkalarının II. (VIII.) asır boyunca hem ehl-i hadis mensuplarına hem de Şiî eğilimli râvilerin giriş çıkışlarına açı olmasına mukabil, hicrî 190-200 seneleri arasında Şiî ilim halkaları müstakilleşmeye başlamıştır. Bu durum hem Sünnî toplumdan dişlanan Şiî cemaat yapısının mezhebî kabullerinin netleşmeye başlaması hem de Şiî cemaatlerin kendi ilim halkalarını sürdürebilecek ilmî birikime kavuşmasıyla ilgilidir. Bilgi geçişkenlikleri tek başına bir sorun değilse de aktarılan bilgilerin mezhebî kabuller çerçevesinde ne gibi tasarruflara uğradığının, kasıtlı ilâveler ve eksiltmeler aracılığı ile ya da bizâtihi rivayetin yeni bir bağlam içerisine yerleștirilmesi suretiyle ne gibi değişikliklere mâruz kaldığının tespiti meselesi etraflıca ele alınmayı beklemektedir.

Çalışma esnasında Ehl-i sünnet ile Şîa arasında polemiklere konu olmuş örnek rivayetlerde bağlam inşasına gidilip gidilmediği incelenirken rivayetin Sünnî eserlerdeki farklı tariklerinin yanı sıra Şî̀ kaynaklarda nasıl yer aldığı da tespit edilecektir. Bu noktada çoğu zaman fezâil veya mesâlib çerçevesine giren hadis metinlerinin aynîliği en önemli hareket noktası olsa da en az metinler kadar önemli bir diğer husus bizâtihi isnadın kendisidir. Zira geçişkenliği temin eden râvileri tespit etmenin en güvenilir yolu rivayetin farklı tariklerini incelemektir. Bununla birlikte söz konusu rivayetlerin aslî bağlamları, varsa vürut bilgileri sayesinde belirlenecek, nakledilme bağlamları için ise tespit edilebildiği takdirde irat çerçevesine giren bilgilere başvurulacaktır. Daha sonra aynı rivayetin Şiî eserlerde ne şekilde yer aldığı ve olası bağlam inşasından ya da bazı şâz Sünnî rivayetlerdeki bağlamın Şiî halkalara intikalinden hangi râvilerin sorumlu olduğu incelenecektir. 
Çalışmada herhangi bir kitap ya da dönem kaydı gözetmek yerine bağlam inşasının yukarıda zikredilen türevleri çerçevesinde doğrudan rivayet sayısıyla bir kayıtlamaya gitmek daha işlevsel görünmektedir. Her hâlükârda burada önem arzeden nokta Sünnî ve Şiî hadis tarihlerinin erken dönemine dair bazı tahminler yürütebilmektir. Bundan dolayı ilgili başlıklar altında sunulacak temsil kabiliyeti yüksek iki veya üç örnek, tablonun netleşmesine imkân verecektir. Rivayet seçimlerinde Sünnî âlimlerce sorunsuz görüldüğü, Şiî âlimlerce de itikadî düşünceyi desteklediği için nakledilen Hz. Ali (ö. 40/661) veya Ehlibeyt' in faziletini öne çıkaran rivayetlerin yanı sıra birtakım sahâbîler hakkında eleştirel bir muhteva taşıyan haberler de (mesâlib, meâyib) dikkate alınabilir. Burada farklı eserlerdeki çok sayıda rivayet gözden geçirilmesine rağmen geçişkenliğin takip edilebildiği haberler tercih edilecektir. Bu haberlerden "Münafığın buğzu, müminin sevgisi", "Ene harbün/Savaşçııı..." ve "Ali’nin kapısı" rivayetleri inşa edilen veya değişen bağlamlar, "On iki halife" ve "Allah yüzünü ak etsin" rivayetleri ise anlam kaymaları çerçevesinde tahlil edilecektir.

\section{Yeniden İnşa Edilen / Değişen Bağlamlar}

Her iki ekolün kaynaklarında tespit edilen rivayetlerdeki bağlam değişiklikleri birkaç surette gerçekleşebilmektedir. Bunların ilki Sünnî kaynaklarda bir bağlamla ya da herhangi bir arka plan bilgisi olmaksızın ve muhtasar olarak yer alan bir haberin, Şiî kaynaklarda tam olarak fakat farklı bir arka plan bilgisiyle sunulması veya Sünnî kaynaklarda yer alan nispeten uzun bir haberin taktî̀ yapılarak ve aslî çerçevesinden ayrılarak Şiî kaynaklardaki etraflı bir anlatının içerisine yerleştirilmesidir.

\section{A) "Münafığın Buğzu, Müminin Sevgisi” Rivayeti}

Sünnî kaynaklarda "sadece münafık olan kimsenin Hz. Ali'ye kin güdeceği, sadece mümin olan kimsenin onu seveceği”ni ifade eden rivayetler farklı isnatlarla ve zaman zaman değişik bağlamlarla yer alır. Kronolojik olarak takip edilecek olursa Ahmed b. Hanbel'in (ö. 241/855) "İbn Nümeyr $\rightarrow$ A'meş $\rightarrow$ Adî b. Sâbit $\rightarrow$ Zir b. Hubeyş" senediyle naklettiğine göre Hz. Ali, "Allah resulünün bana vaat ettiği şeylerden biri de bana sadece münafığın buğzedeceği ve beni sadece müminin seveceğidir” demiştir. ${ }^{4}$ Rivayet başka

4 Ahmed b. Hanbel, el-Müsned, II, 71; rivayet ufak metin farklılıkları ve "A'meş $\rightarrow$ Adî b. Sâbit $\rightarrow$ Zir b. Hubeyş $\rightarrow$ Hz. Ali” senediyle pek çok kaynakta yer alır (bk. Humeydî, el-Müsned, I, 31; İbn Ebû Şeybe, el-Musannef, XVII, 94; Müslim, "Îmân", 131; Tirmizî, "Menâkıb", 21; İbn Mâce, "Mukaddime”, 11; İbn Ebû Âsım, es-Sünne, II, 888; Bezzâr, elBahrü'z-zehhâr, II, 182; Nesâî, "Îmân”, 19, 20; Ebû Ya'lâ, el-Müsned, I, 250. 
tariklerle de Hz. Aliden gelir. Nitekim Belâzürînin (ö. 279/892-93) "Hüdbe b. Hâlid $\rightarrow$ Mübârek b. Fedâle $\rightarrow$ Hasan" senediyle tahriç ettiğine göre Hz. Ali şöyle demiştir:

Tohumu yaran ve canlıları yaratana yemin olsun ki Resûl-i Ekrem bana, "beni münafığın sevmeyeceğini, müminin ise buğzetmeyeceğini” haber verdi..$^{5}$

Ebû Ya'lâ el-Mevsîlî ise (ö. 307/919) benzer bir rivayeti, "Ubeydullah b. Ömer $\rightarrow$ Ca'fer b. Süleyman $\rightarrow$ Nadr b. Humeyd $\rightarrow$ Ebü’l-Cârûd $\rightarrow$ Hâris elHemdânî" senediyle nakleder. Buna göre Hz. Ali, Allah’a hamdüsenâ ettikten sonra şöyle demiştir:

Allah’ın nebînizin diliyle verdiği hükümlerden biri şudur: Beni sadece mümin sever, bana sadece münafik buğzeder. İftira atan kaybetmiştir. Nadr'ın ifadesine göre Ali, "Ben Resûl-i Ekrem'in kardeşiyim, amcasının oğluyum, bunu benden başka kimse söyleyemez" demiştir. ${ }^{6}$

İsnatta yer alan Hâris b. Abdullah el-Hemdânî (ö. 65/684), ${ }^{7}$ Ebü'lCârûd Ziyâd b. Münzir (ö. 150/767[?]) ${ }^{8}$ ve Ca'fer b. Süleyman ed-Dubaî (ö. 177/793) ${ }^{9}$ Şî̂ eğilimler taşıdıkları gerekçesiyle eleştirilen râvilerdir. Öte yandan rivayetin sonunda Nadr tarafindan Hz. Aliden nakledilen ifadeler diğer rivayetlerde yer almaz.

"Huldî" diye bilinen Ca'fer b. Muhammed el-Bağdâdî ise (ö. 348/959) "Kāsım b. Muhammed b. Hammâd $\rightarrow$ Ahmed b. Subeyh $\rightarrow$ Rebî‘ b. Sehl $\rightarrow$ Saîd b. Ubeyd $\rightarrow$ Ali b. Rebîa" senediyle Hz. Ali’nin minberde, "Ümmî Peygamber bana, 'Seni ancak mümin sever, sana sadece münafik buğzeder' diye vaatte bulundu" dediğini nakleder. ${ }^{10}$ Rivayetin senedindeki Ahmed b. Subeyh el-Kûfî hakkında Sünnî eserlerde çok fazla bilgi olmasa da Ali b. Hüseyin b. Cüneyd (ö. 291/904) onun için "sadûk" demiştir. ${ }^{11}$ Şiî rical eserlerinde ise "sika" olarak anılan râvinin bazı kitaplarından bahsedilir. ${ }^{12}$

5 Belâzürî, Ensâb, II, 383. Bu rivayet Hasan-1 Basrînnin Hz. Ali ile görüşmemesi dolayısıyla munkatı' kabul edilmelidir.

6 Ebû Ya'lâ, el-Müsned, I, 347.

7 Buhârî, et-Târîhu'l-kebîr, II, 273; İbn Ebû Hâtim, el-Cerh, III, 79.

8 Yahyâ b. Maîn, et-Târîh (Dûrî), III, 456, 560; Buhârî, et-Târîhu'l-kebîr, III, 372; Ahmed b. Hanbel, el-İlel, III, 382; İbn Ebû Hâtim, el-Cerh, III, 546.

9 İbn Sa'd, et-Tabakāt, VII, 288; İclî, Ma'rifetüs-sikāt, I, 268; İbn Kuteybe, el-Maârif, s. 624; İbn Hibbân, es-Sikāt, VI, 140.

10 Ca'fer el-Huldî, el-Fevâid, s. 15.

11 İbn Ebû Hâtim, el-Cerh, II, 56 .

12 Necâşî, er-Ricâl, s. 76; Tûsî, el-Fihrist, s. 66; ayrıca bk. Tüsterî, Kāmûs, I, 479-48o; Hûî, Mu'cem, II, 127-28. 
Rivayet Hz. Ali dışında bazı sahâbîlerden de gelir. Nitekim İbn Ebû Şeybe’nin (ö. 235/849) el-Musannef inde, "Hâlid b. Mahled $\rightarrow$ Muhammed b. Fudayl $\rightarrow$ Abdullah b. Abdurrahman Ebü’n-Nadr $\rightarrow$ Müsâvir el-Himyerî $\rightarrow$ annesi" senediyle rivayet ettiğine göre Ümmü Seleme (ö. 62/681) şöyle demiştir: "Allah resulünü Ali'ye, 'Mümin Ali'ye buğzetmez, münafik onu sevmez' buyururken işittim." I3 İsnattaki Muhammed b. Fudayl (ö. 195/810) ve Hâlid b. Mahled'in (ö. 213/828) ${ }^{14}$ Şî̂ eğilimlerinden söz edilmiştir. ${ }^{15}$

Ahmed b. Hanbel'in, "Saîd b. Muhammed el-Varrâk $\rightarrow$ Ali b. Hazavver $\rightarrow$ Ebû Meryem es-Sekafî" senediyle naklettiğine göre Ammâr b. Yâsir şöyle demiştir: "Allah resulünü Ali'ye, 'Ali! Seni seven ve hakkında doğru söyleyene müjdeler olsun. Sana buğzeden ve hakkında yalan söyleyene de yazıklar olsun!' buyururken işittim." ${ }^{16}$ İsnattaki Ali b. Hazavver Şiî eğilimli olmakla itham edilen zayıf bir râvidir. ${ }^{17}$ İsminin Kays olduğu ifade edilen Ebû Meryem es-Sekafî1 ${ }^{18}$ ise meçhuldür.

İbn Ebû Âsım ise (ö. 287/900) rivayeti daha etraflı bir arka planla nakletmiştir. Onun, "Muhammed b. Musaffâ $\rightarrow$ Süveyd b. Abdülazîz $\rightarrow$ Dâvûd b. Ali $\rightarrow$ Abdullah b. Atâ $\rightarrow$ Muhabber" senediyle rivayet ettiğine göre ise Huzeyfe b. Esîd el-Gıfârî (ö. 42/662) şöyle demiştir:

Allah resulü ile Ali b. Ebû Tâlib’in evine gitmiştik. Ona "Halin nice olacak? Sen bir toplulukta bulunup onlara gerçeği söylediğinde, onların nazarında ümmetin en yalancısı olacaksın” dedi. (Huzeyfe), "Ali’nin yüzü renkten renge girdi” demiştir. Bunun üzerine Allah resulü, "Seni sevenin beni sevecek olmasına ve havuzun başında bana ulaşmasına, sana buğzedenin bana buğzetmiş olmasına razı değil misin?” buyurdu. (Ali) “Tabii ki razıyım Allah'in elçisi” dedi. ${ }^{19}$

13 İbn Ebû Şeybe, el-Musannef, XVII, 126. Rivayet aynı isnatla ve küçük lafız farklılıkları ile başka kaynaklarda da yer alır (Ahmed b. Hanbel, el-Müsned, XLIV, 117; a.mlf., Fezâilü̉s-sahâbe, II, 619, 648, 685; Tirmizî, “Menâkıb”, 21; İbn Ebû Âsım, es-Sünne, II, 885; Ebû Ya'lâ, el-Müsned, XII, 331-32, 362).

14 İclî, Ma'rifetüs-sikāt, I, 332; Zehebî, Mîzânül'-i'tidâl, I, 591. Râvi hakkında Yahyâ b. Maîn "leyse bihî be’s" (et-Târîh [Dârimî], s. 105), Ahmed b. Hanbel, "Münker hadisleri vardır" demiştir (el-ïlel, II, 17).

15 İbn Sa'd, et-Tabakāt, VI, 389; İbn Ebû Hâtim, el-Cerh, VIII, 57; İclî, Ma'rifetüs-sikāt, II, 250; Zehebî, el-Kâsşif, III, 89; İbn Hacer, Takrîb, s. 502.

16 Ahmed b. Hanbel, Fezâilüs-sahâbe, II, 680; Ebû Ya'lâ, el-Müsned, III, 179.

17 Yahyâ b. Maîn, et-Târîh (Dûrî), III, 420; Nesâî, ed-Duafầ, s. 179; İbn Ebû Hâtim, el-Cerh, VI, 182. Şî̂lik ithamı için bk. İbn Adî, el-Kâmil, VI, 152.

18 Buhârî, et-Târîhu'l-kebîr, VII, 151; İbn Ebû Hâtim, el-Cerh, VII, 106. Meçhul olduğuna dair bk. İbn Hacer, Takrîb, s. 672.

19 İbn Ebû Âsım, es-Sünne, I, 513-14. 
İlgili ifadenin söylenme ortamını vererek diğer rivayetlerden ayrılan bu haberin isnadındaki râvilerden herhangi biri için Şiîlik ithamı tespit edilememiştir.

Taberânînin (ö. 360/971) "Abdurrahman b. Selm $\rightarrow$ Ebü’l-Ezher enNîsâbûrî $\rightarrow$ Abdürrezzâk $\rightarrow$ Ma'mer $\rightarrow$ Zührî $\rightarrow$ Ubeydullah b. Abdullah" senediyle naklettiğine göre İbn Abbas (ö. 68/687-8) şöyle demiştir:

Hz. Peygamber Ali'ye bakıp, 'Seni sadece mümin sever, sana sadece münafik buğzeder. Seni seven beni sevmiş olur, sana buğzeden bana buğzetmiş olur. Benim sevdiğim Allah’n sevdiğidir, benim buğzettiğim Allah’n buğzettiğidir. Benden sonra sana buğzedene yazıklar olsun’ buyurdu. ${ }^{20}$

Taberânî, bu hadisi Abdürrezzâk'tan (ö. 211/826-27) Ebü'l-Ezher enNîsâbûrîden (ö. 263/877) başkasının rivayet etmediğini söyler. Yine onun, "Osman b. Hişâm b. Fazl $\rightarrow$ Muhammed b. Kesîr $\rightarrow$ Hâris b. Hasîra $\rightarrow$ Ebû Dâvûd es-Sebîî $\rightarrow$ İmrân b. Husayn" senediyle naklettiğine göre Hz. Peygamber Hz. Ali'ye, "Seni ancak mümin sever, sana ancak münafik buğzeder" buyurmuştur. ${ }^{21}$ Abdürrezzâk'in ${ }^{22}$ yanı sıra isnattaki Ebû Dâvûd Nüfey' b. Hâris es-Sebîi (ö. 100, 110/718, 728), ${ }^{23}$ Hâris b. Hasîra ${ }^{24}$ ve Muhammed b. Kesîr el-Kûfî̀ ${ }^{25}$ de Şiî eğilimler taşımakla itham edilmiştir.

Sonuç olarak Sünnî kaynaklarda farklı isnatlarla gelen bu metinlerin geneli oldukça muhtasardır. Bunun tek istisnası olan İbn Ebû Âsım rivayetinde Hz. Ali, gerçekleşecek birtakım olaylar hakkında bilgilendirilir. Dikkat çekici bir şekilde, ele alınan rivayetin farklı isnatlarında yer alan ve geneli Kûfeli olan pek çok râvi Şiî eğilimler taşıdıkları gerekçesiyle eleştirilmiştir ve bu tenkitlerin bir kısmı Şiî kaynaklarca da doğrulanır. İlgili râvilerin, rivayetin Sünnî kaynaklardan Şiî kaynaklara intikalinde rol aldığı düşünülebilir. Ancak hem bu durumu tespiti hem de olası bağlam farklılaşmaları açısından rivayetin izini Şiî kaynaklarda da sürmek gereklidir.

Tespit edilebildiği kadarıyla söz konusu rivayet Şiî kaynaklarda en erken Ca'fer b. Muhammed b. Şüreyh'in (II-III./VIII-IX. asır) el-Asl'ında, "Humeyd b. Şuayb $\rightarrow$ Câbir $\rightarrow$ Ebû Ca'fer [Muhammed el-Bâkır]" isnadıyla yer almaktadır. Buna göre Allah resulü şöyle buyurmuştur:

20 Taberânî, el-Mu'cemül-evsat, V, 87.

21 Taberânî, el-Mu'cemü'l-evsat, II, 337.

22 Geniş bilgi için bk. Tokpınar, “Abdurrazzak B. Hemmam (126-211/744 827)'nn Şiilikle İtham Edilmesi Üzerine Bir İnceleme”, 3/9, s. 77-92; 4/10, s. 71-88.

23 Cûzcânî, Ahvâlürr-ricâl, s. 65; Ukaylî, ed-Duafầ, IV, 306; İbn Adî, el-Kâmil, VIII, 151-53.

24 Ebû Dâvûd, Suâlât, s. 84; İbn Adî, el-Kâmil, II, 417-19.

25 Yahyâ b. Maîn, et-Târîh (Dûrî), III, 478. 
Ali'yi seven beni, beni seven Allah’ı sevmiştir. Ali'ye buğzeden bana, bana buğzeden Allah'a buğzetmiştir. Allahım! Ali'yi seveni sen de sev, Ali'ye buğzedene sen de buğzet! Allahım! Ben Ali’yi seviyorum, sen de onu sev!²6

Sünnî kaynaklardaki rivayetlerden farklılık arzetmeyen nakildeki en dikkat çekici husus isnattaki Câbir el-Cu'fîdir (ö. 128/745). Pek çok noktada iki ekolün kesiştiği bir isim olan Câbir’e bu rivayetin râvisi olarak Sünnî kaynaklarda hiç tesadüf edilmez. Rivayetin Muhammed el-Bâkır ile (ö. 114/733[?]) Hz. Peygamber arasındaki isnadı bilinmese de, isnattaki inkıtâ Şiî hadis anlayışı açısından sorun teşkil etmez. Zira imamın sözü, bizâtihi Allah resulünün sözü anlamına gelmektedir.

Rivayete Furât b. İbrâhim el-Kûfînnin (III-IV./IX-X. yüzyıl) Tefsîr'inde, onun hocası olan Kāsım b. Hammâd ed-Dellâl ile Muhammed el-Bâkır arasındaki isnat hazfedilerek yer verilmiştir. Şöyle ki: Neml sûresinin, aslında müşriklere hitap eden ve Allah’ın yaratmasına vurgu yapan 60-64. âyetinin yer aldığı pasajın nâzil olması üzerine Hz. Peygamber' in yanında bulunan $\mathrm{Hz}$. Ali tıpkı bir serçe gibi titremiş, Hz. Peygamber'in, “Ali! Ne oldu?” demesi üzerine, "İnsanların Allah'a olan cüretine mukabil Allah’ın onlara olan hilmine hayret ettim” cevabını vermiştir. Bu söz üzerine Allah resulü onun sırtını sıvazlayıp şöyle buyurmuştur: "Müjde sana Ali! Seni münafık sevmez, sana mümin buğzetmez. Sen olmasan Allah’ın hizbi ve onun resulünün hizbi bilinmezdi."27

İsnat bakımından bir önceki rivayette olduğu gibi Muhammed elBâkır'dan gelen haberde Hz. Peygamber'in ifadeleri Neml sûresindeki bazı âyetler etrafında gerçekleşen bir diyalog sonucuymuş gibi sunulmuş, rivayetin sonunda ise İmâmî itikadın Hz. Ali’ye yüklediği misyon yer almıştır. Bu haliyle rivayetin Şiî kaynaklara geçişini ve bağlam değişiminin sorumlusunu takip etmek mümkün değildir. Ancak Şî̂ kaynaklarda yer alan bazı haberler hem Neml sûresindeki ilgili pasajdan hangi âyetin konuyla ilişkili kılındığını hem de geçişkenliği takip etme imkânı vermektedir.

Şeyh Müfîd'in (ö. 413/1022) "Muhammed b. Ömer el-Ciâbî $\rightarrow$ Ebü’lAbbas Ahmed b. Muhammed b. Saîd [İbn Ukde] $\rightarrow$ Ca'fer b. Muhammed b. Mervân $\rightarrow$ babası $\rightarrow$ İbrâhim b. Hakem $\rightarrow$ Mes'ûdî $\rightarrow$ Hâris b. Hasîra" isnadıyla rivayet ettiğine göre İmrân b. Husayn (ö. 52/672) şöyle demiştir:

Ben ve Ömer Hz. Peygamber'in yanında oturuyorduk. Ali de onun yanında oturuyordu. Allah resulü, "Darda kalmış kimsenin duasını kabul edip onun sıkıntısın gideren ve sizi yeryüzünde halifeler kılan Allah mı üstün, yoksa O’na ortak koştuklarınız mı? Hiç Allah ile birlikte başka bir ilâh olur

26 el-Usûlüs-sitte aşer, s. 214.

27 Kûfî, Tefsîr, s. 310. 
mu! Ne de düşüncesizsiniz!"28 âyetini okudu. Bunun üzerine Ali tıpkı bir serçe gibi titredi. Hz. Peygamber ona, "Ne bu halin, niye kaygılandın?" diye sordu. O, "Allah bizi yeryüzünün halifeleri kılmışken nasıl kaygılanmayayım!" cevabını verdi. Bunun üzerine Hz. Peygamber ona, "Endişelenme! Vallahi seni ancak mümin olan sever, sana ancak münafik olan buğzeder" buyurdu. ${ }^{29}$

Daha önce verilen "Osman b. Hişâm b. Fazl $\rightarrow$ Muhammed b. Kesîr $\rightarrow$ Hâris b. Hasîra $\rightarrow$ Ebû Dâvûd es-Sebîi $\rightarrow$ İmrân b. Husayn” isnatlı Taberânî rivayeti, metnin sadece son kısmını içerir. Müfìd rivayeti ise görüldüğü üzere hayli farklı bir bağlam bilgisiyle kaydedilmiştir. Ancak tek farklılık bağlam değil, Hâris'in değişen hocaları ve talebeleridir. Taberânî rivayetinde o, sahâbî İmrân'a Ebû Dâvûd es-Sebîî vasıtasıyla ulaşırken Müfìd rivayetinde metni doğrudan İmrân'dan aktarır. Zira Taberânî rivayetinde haberi ondan alan isim Muhammed b. Kesîr iken Müfîd rivayetinde Mes'ûdîddir. Burada adı geçen Mes'ûdî, Ebû Abdurrahman Abdullah b. Abdülmelik el-Hüzelî elKureşî olup Şî̀ eğilimler taşımakla itham edilmiştir. ${ }^{30}$ Dolayısıyla Hâris'in yanı sıra rivayeti ondan nakleden her iki râvi yani Muhammed b. Kesîr ve Mes'ûdî Şîilik ithamına mâruz kalmıştır.

Rivayetin Muhammed b. Kesîr'den gelen Sünnî versiyonunun bağlam bakımından Müfîd metninden farklı olması, Hâris'in rivayeti farklı zamanlarda farklı şekillerde almış ve/veya nakletmiş olmasından, Taberânî rivayetinin isnattaki bir râvi veya Taberânî tarafından muhtasar olarak nakledilmesinden ya da Mes'ûdînnin rivayeti Şiî ders halkalarına farklı bir bağlamla aktarmış olmasından kaynaklanmış olabilir. Ancak rivayetin, net bir yargıya varmaya imkân verecek daha başka tarikleri yoktur. Bununla birlikte geçişkenliği mezkûr üç isimden hangisi temin etmiş olursa olsun, haberin Şiî ders halkalarına II. (VIII.) yüzyılda geçtiği açıktır.

Rivayete daha yakından bakıldığında Hz. Ömer (ö. 23/644), Hz. Ali ve İmrân’n Hz. Peygamber' in yanında oturdukları, Allah resulünün halife kelimesini içeren bir âyeti okuması üzerine Ali’nin kaygılandığı, endişesinin ise, "Seni ancak mümin olan sever, sana ancak münafik olan buğzeder" ifadesiyle giderildiği bildirilir. Beş âyetin bahse konu edildiği Furât el-Kûfî rivayetinin aksine, burada içerisinde halife kelimesi geçen âyet anlatının merkezine yerleşmiştir. Her hâlükârda ilgili âyet etrafındaki konuşmaların Hz. Ali üzerinden sürmesi ve bazı muahhar kaynaklarda Ali’nin yeryüzünde görev alarak

28 en-Neml 27/62.

29 Müfîd, el-Emâlî, s. 307-308. Rivayet aynı isnat ve metinle Tûsî tarafından nakledilir (el-Emâlî, s. 129-30).

30 Ukaylî, ed-Duafầ, II, 275; Zehebî, Mîzânü'l-i'tidâl, II, 409. 
imtihana tâbi tutulma endişesiyle titrediğinin ve ayrıca sevme ve buğzetme hakkındaki yargıların kıyamete kadar süreceğinin belirtilmesi, ${ }^{31}$ âyetin $\mathrm{Hz}$. Ali ve Ehlibeyt hakkında siyasî bir tayin gibi okunmasını mümkün kılar. Sonuç olarak hadisin bu tariki Sünnî kaynaklarda söylenme ortamına dair herhangi bir kayıt içermeksizin verilmiştir ve ilgili âyetteki halife kavramı da insanın yeryüzündeki sorumluluğu ile ilgilidir. Buna rağmen ilgili kavram Şî̀ kaynaklarda oldukça farklı bir bağlama yani siyasî bir zemine yerleştirilmiş olmaktadır.

Tûsînin (ö. 460/1067), "Ebû Ömer [Abdülvâhid b. Muhammed] $\rightarrow$ Ahmed [b. Muhammed b. Saîd İbn Ukde] $\rightarrow$ Ahmed b. Muhammed b. Yahyâ el-Cưfî el-Hâzimî $\rightarrow$ babası $\rightarrow$ Ziyâd b. Hayseme ve Züheyr b. Muâviye $\rightarrow$ A'meş $\rightarrow$ Adî b. Sâbit $\rightarrow$ Zir b. Hubeyş" isnadıyla rivayet ettiğine göre Hz. Ali şöyle demiştir: "Allah resulünün bana vaat ettiği şeylerden biri şudur: Sana sadece münafık buğzeder ve seni sadece mümin sever." ${ }^{32}$ Rivayetin Sünnî kaynaklarda da bu lafızla geçtiğine temas edilmişti.

Ahmed b. Hanbel rivayetinde, rivayeti A'meş'ten (ö. 148/765) alan kişi Abdullah b. Nümeyr iken (ö. 199/814) burada Ziyâd b. Hayseme ve Züheyr b. Muâviye (ö. 172/750) adları dikkat çeker. Ancak her ikisi de Sünnî eserlerde ta'dîl edilen ve Şî̀ eğilimlerinden bahsedilmeyen bu râvilerin bilgi geçişkenliğinden sorumlu olma ihtimalleri oldukça düşüktür. Bu durumda Tûsîye daha yakın isimlere bakılmalıdır. Ziyâd'ın talebeleri arasında Yahyâ el-Cưfî adına tesadüf ediliyorsa da buradaki isnatta Ahmed b. Muhammed b. Yahyầnın, babası Muhammed b. Yahyầdan nakilde bulunduğu görülür. Dârekutnî (ö. 385/995) tarafından zayıf kabul edilen Ahmed b. Muhammed b. Yahyâ el-Cúfî̀nin Şiîliğinden bahsedilmez. Ancak yukarıdaki rivayeti de ondan alan İbn Ukde’nin (ö. 332/944) kendisinden çokça rivayette bulunduğu kaydedilir. ${ }^{33} \mathrm{Bu}$ durumda rivayetin ciddi bir bağlam değişikliği barındırmayan bu tarikinin IV. (X.) asrın ilk çeyreğinde Zeydî-Şiî kimliği ile tanınan İbn $\mathrm{Ukde}^{34}$ tarafından Şiî ilim halkalarına taşındığı düşünülebilir. Rivayeti Şiî eserlere İbn Ukde’nin taşıdığ kabul edildiği takdirde, bu durumun geçişkenliklerin yoğun olarak görüldügü iki tarihî dönem olan, "hicrî II. asrın sonu ve hicrî III. asrın başı" ve "hicrî IV. asrın ilk yarısı"35 ihtimallerinden ikincisi yani IV. asrın ilk çeyreği ile uyum arzettiği ifade edilmelidir.

31 İbn Şehrâşûb, Menâkıb, II, 119.

32 Tûsî, el-Emâlî, s. 393 .

33 Zehebî, Mîzânül-i'tidâl, I, 167.

34 İbn Ukde hakkında ayrıntılı bilgi için bk. Sandıkçı, “İbn Ukde”, s. 427-28.

35 İlgili geçiş dönemleri hakkında etraflı bilgi için bk. Kuzudişli, "Sunnī-Shīī Interaction in the Early Period", s. 7-45. 
Sonuç olarak hem Müfîd hem de Tûsî isnatları rivayet geçişkenliği hakkında birtakım bilgiler sunmaktadır. Bu çalışma açısından daha önemli olan nokta ise özellikle Furât b. İbrâhim ve Müfîd rivayetlerinde haberin farklı bir bağlama yerleştirilmiş olmasıdır. İncelenen Sünnî isnatlarda Şiî eğilimler taşıdıkları gerekçesiyle eleştirilen birçok râvinin yer aldığı ve hadisin bu râvilerin bazıları tarafından farklı bağlamlarla Şiî ilim halkalarına aktarıldığı görülür. Her hâlükârda henüz Sünnî ve Şiî ilim halkalarının iç içe olduğu II. (VIII.) yüzyılda bu intikalin gerçekleştiği ve bağlam farklılaşmasının bu geçişle eş zamanlı ya da yakın aralıklı olmak üzere art zamanlı olarak meydana geldiği, sonraki eserlerde ise birtakım âyetlerin konu etrafında metne eklemlendiği düşünülebilir.

\section{B) “Ene Harbün..." Rivayeti}

Hz. Peygamber'in Hz. Ali ve ailesi hakkında, "onlarla savaşanla savaşacağı, onlarla iyi geçinenlerle de iyi geçineceğini” beyan eden rivayet, Sünnî kaynaklarda Ebû Hüreyre (ö. 58/678), Zeyd b. Erkam (ö. 68/688), Ümmü Seleme ve Ebû Saîd el-Hudrî (ö. 74/693-94) olmak üzere dört farklı sahâbîden gelmektedir. Zeyd b. Erkam rivayetini İbn Ebû Şeybe "Mâlik b. İsmâil $\rightarrow$ Esbât b. Nasr $\rightarrow$ Süddî $\rightarrow$ Ümmü Seleme’nin mevlâsı Subeyh $\rightarrow$ Zeyd b. Erkam” isnadıyla nakleder. Buna göre Hz. Peygamber, Fâtıma, Hasan ve Hüseyin’e bakıp, "Sizinle savaşanla savaşırım, sizinle barış içinde olanla da barışık olurum" buyurmuştur. ${ }^{36}$ Görüldüğü üzere buradaki metin oldukça kısadır ve sözün hangi hadiseye binaen söylendiğini bu rivayetten hareketle tespit etme imkânı yoktur. İsnattaki İsmâil b. Abdurrahman b. Ebû Kerîme es-Süddî (ö. 127/744) ${ }^{37}$ ile Mâlik b. İsmâil'in (ö. 219/834) Şiî eğilimler taşıdığ 1 söylenmiştir. ${ }^{38}$

Tirmizînin (ö. 279/892) "Süleyman b. Abdülcebbâr el-Bağdâdî $\rightarrow$ Ali b. Kādim $\rightarrow$ Esbât b. Nasr $\rightarrow$ Süddî $\rightarrow$ Ümmü Seleme’nin mevlâsı Subeyh $\rightarrow$ Zeyd b. Erkam" isnadıyla naklettiği rivayet de çok fazla ayrıntı sunmaz. Bu rivayete göre Hz. Peygamber, Ali, Fâtıma, Hasan ve Hüseyin'e, "Sizinle savaşanla savaşırım, sizinle barış içinde olanla da barışık olurum" buyurmuştur. Tirmizî rivayetin ardından, "Bu garîb bir hadistir. Hadisi sadece bu tarikle biliyoruz. Ümmü Seleme’nin mevlâsı Subeyh mâruf değildir” der. ${ }^{39}$ İbn Mâce

36 İbn Ebû Şeybe, el-Musannef, XVII, 163. İbn Hibbân da (ö. 354/965) hadise onun isnadiyla yer verir (Sahîh, XV, 433).

37 Cûzcânî, Ahvâlür-ricâl, s. 48; Aynî, Megānill-ahyâr, I, 53; İbn Hacer, Takrîb, s. 108.

38 İbn Sa'd, et-Tabakāt, VI, 404; Cûzcânî, Ahvâlürr-ricâl, s. 83; Zehebî, Siyer, X, 432.

39 Tirmizî, "Menâkıb", 60. 
(ö. 273/887) aynı rivayete, "Hasan b. Ali el-Hallâl ve Ali b. el-Münzir $\rightarrow$ Ebû Gassân [Mâlik b. İsmâil] $\rightarrow$ Esbât b. Nasr...” isnadıyla yer verir. ${ }^{40}$ Tirmizî isnadında Süddî ve Ali b. Kādim (ö. 213/828), ${ }^{41}$ İbn Mâce isnadında ise Mâlik b. İsmâil (ö. 217/832) ve Ali b. Münzir (ö. 256/869) Şiî eğilimler taşımakla itham edilmiştir. ${ }^{42}$ Rivayet "Yûsuf b. Mûsâ $\rightarrow$ Ebû Gassân..." isnadıyla Bezzâr (ö. 292/905) tarafından da nakledilir. Metin bakımından farklılık arzetmeyen bu rivayetin ardından Bezzâr bu hadisi Hz. Peygamber'den sadece Zeyd'in naklettiğini belirtip Zeyd'den de bu tarîk dışında nakledildiğini bilmediğini söyler. Ayrıca Subeyh'ten nakilde bulunan tek kişinin Süddî olduğunu da sözlerine ekler. ${ }^{43}$

Rivayete "İbrâhim $\rightarrow$ Muhammed b. Merzûk $\rightarrow$ Hüseyin b. Hasan elEşkar $\rightarrow$ Ubeydullah b. Mûsâ $\rightarrow$ Ebû Madâ $\rightarrow$ İbrâhim b. Abdurrahman b. Subeyh $\rightarrow$ dedesi Subeyh" isnadıyla yer veren Taberânî rivayeti ise şöyledir: Ben Allah resulünün kapısındaydım. O esnada Ali, Fâtıma, Hasan ve Hüseyin gelerek bir köşeye oturdular. Allah resulü yanımıza gelip, "Siz hayır üzeresiniz" buyurdu. O esnada üzerinde Hayber işi bir cübbe vardı [kisâ]. Onunla onları örttü ve şöyle buyurdu: "Sizinle savaşanla savaşırım, sizinle barış içinde olanla da barışık olurum.” Taberânî hadisin Subeyh'ten sadece bu isnatla rivayet edildiğini, Subeyh'ten bunu nakletmede Hüseyin elEşkar’ın (ö. 208/823) teferrüt ettiğini, Süddînin ise hadisi, "Subeyh $\rightarrow$ Zeyd b. Erkam” isnadıyla naklettiğini söylemektedir. ${ }^{44}$ Görüldüğü üzere bu ikinci rivayette ilk isnadın aksine Zeyd b. Erkam anılmamışsa da rivayet bağlam açısından daha fazla bilgi içerir. İbn Asâkir'in (ö. 571/1176) “... $\rightarrow$ Süleyman b. Karm $\rightarrow$ Ebü'l-Cahhâf $\rightarrow$ İbrâhim b. Abdurrahman b. Subeyh...” isnadiyla kaydettiği rivayette Hz. Peygamber'in içerisinde Hz. Ali, Hz. Fâtıma, Hasan ve Hüseyin'in bulunduğu bir eve gelip bu sözleri sarfettiği yer alır. ${ }^{45}$ Öte yandan Taberânî ve İbn Asâkir isnatlarında da Hüseyin el-Eşkar, ${ }^{46}$ Ubeydullâh b. Mûsâ (ö. 213/828) ${ }^{47}$ ve Süleyman b. Karm ${ }^{48}$ Şiî eğilimler taşıdıkları gerekçesiyle itham edilen râvilerdir.

40 İbn Mâce, "Mukaddime", 11.

41 İbn Sa'd, et-Tabakāt, VI, 404; İbn Hacer, Takrîb, s. 404.

42 Zehebî, Mîzânül-itidâl, III, 168; IV, 5; İbn Hacer, Takrîb, s. 405.

43 Bezzâr, el-Bahrüz-zehhâr, X, 228-29.

44 Taberânî, el-Mu'cemüll-evsat, III, 179. Zeyd b. Erkam’ın zikredildiği Süddî rivayeti için ayrica bk. V, 182.

45 İbn Asâkir, Târîh, XIII, 219.

46 Yahyâ b. Maîn, Suâlât, II, 344; Ahmed b. Hanbel, Suâlât, s. 116; İbn Hacer, Takrîb, s. 166. 47 İclî, Ma'rifetü's-sikāt, II, 114; krş. I, 39; İbn Kuteybe, el-Maârif, s. 519; Fesevî, el-Ma'rife,

III, 140; İbn Hibbân, es-Sikāt, VII, 152.

48 İbn Kuteybe, el-Maârif, s. 624; İbnü'l-Mibred, Bahrü'd-dem, s. 187. 
Rivayetin Zeyd b. Erkam'dan gelen versiyonu daha muahhar bir kaynak olan İbn Asâkir'in Târîh'inde, “... $\rightarrow$ Ahmed b. Muhammed et-Temîmî $\rightarrow$ Münzir b. Muhammed b. Münzir $\rightarrow$ babası $\rightarrow$ Hüseyin b. Saîd b. Cehm $\rightarrow$ babası $\rightarrow$ Ebû İshak $\rightarrow$ Zeyd b. Erkam" isnadı ve benzeri bir lafızla yer alır. ${ }^{49}$ Burada Ebû İshak Amr b. Abdullah es-Sebîi (ö. 127/745) Şiî eğilimler taşıdığ gerekçesiyle eleştirilmiştir. ${ }^{50}$

Zeyd b. Erkam'dan gelen rivayetlerde etraflı bir bağlam bilgisi yoksa da isnattaki bazı râvilerin Şiî eğilimlere sahip oldukları gerekçesiyle tenkit edildikleri görülür. Ancak bu râvilerden sadece bazılarının Şiî eğilimleri Şiî kaynaklarca da doğrulanır. Bu râvilerden biri olan Süddî, ileride temas edileceği üzere rivayetin Şiî ilim halkalarına geçişinde önemli bir isim gibi durmaktadir.

Ebû Hüreyre rivayetinin tespit edilebildiği en erken kaynak Ahmed b. Hanbel'in el-Müsned' idir. Burada rivayet "Telîd b. Süleyman $\rightarrow$ Ebü'l-Cahhâf $\rightarrow$ Ebû Hâzim $\rightarrow$ Ebû Hüreyre" isnadı ve "Hz. Peygamber, Ali, Hasan, Hüseyin ve Fâtıma'ya bakıp, 'Sizinle savaşanla savaşırım, sizinle barış içinde olanla da barışı olurum' buyurdu" ifadesiyle yer alır. ${ }^{51}$ Aynı rivayet "Muhammed b. Sâlih b. Zerîh $\rightarrow$ İsmâil b. Mûsâ es-Süddî $\rightarrow$ Telîd b. Süleyman ..." isnadıyla İbn Adî (ö. 365/976) tarafından da kaydedilir. İbn Adî rivayetin, "Ebü’lCahhâf $\rightarrow$ Ebû Hâzim" isnadı haricinde de rivayet edildiğini söyler. ${ }^{52} \mathrm{Bu}$ isnatta Ebü'l-Cahhâf Dâvûd b. Ebû Avf, ${ }^{53}$ Telîd b. Süleyman (ö. 190/805'ten sonra) ${ }^{54}$ ve İsmâil b. Mûsâ (ö. 245/859) ${ }^{55}$ Şî̀ eğilimler taşıdıkları gerekçesiyle tenkit edilmişlerdir. Ebû Hüreyre rivayeti Ahmed b. Hanbel tarikiyle Taberânî ve Hâkim en-Nîsâbûrî (ö. 405/1014) tarafından da kaydedilmiştir. ${ }^{56}$

Rivayet İbn Şâhin (ö. 385/996) tarafından, "Ahmed b. Muhammed b. Saîd b. Abdurrahman el-Hemedânî $\rightarrow$ Ya'kūb b. Yûsuf ed-Dabbî $\rightarrow$ Nasr b. Müzâhim $\rightarrow$ Abdullah b. Müslim el-Mülâî $\rightarrow$ Dâvûd b. Ebû Avf Ebü’l-Cahhâf $\rightarrow$ Atıyye el-Avfî $\rightarrow$ Ebû Saîd el-Hudrî” isnadıyla nakledilir. Buna göre Hz. Ali’nin Hz. Fâtıma ile evlendiği dönemde Hz. Peygamber kırk sabah onların kapısına gelip, "Sizinle savaşanla savaşırım, sizinle barış içinde olanla da

\footnotetext{
49 İbn Asâkir, Târîh, XIII, 218.

50 İbn Kuteybe, el-Maârif, s. 624; Şehristânî, el-Milel, I, 190.

51 Ahmed b. Hanbel, el-Müsned, XV, 436.

52 İbn Adî, el-Kâmil, II, 86.

53 Ukaylî, ed-Duafầ, II, 37; İbn Hacer, Takrîb, s. 199.

54 Yahyâ b. Maîn, et-Târîh (Dûrî), III, 285; İclî, Ma rifetü’s-sikāt, I, 257; Tirmizî, "Menâkıb", 17.

55 İbn Adî, el-Kâmil, I, 477.

56 Taberânî, el-Mu'cemü'l-kebîr, III, 40; Hâkim, el-Müstedrek, III, 149.
} 
barışık olurum" buyurmuştur. ${ }^{57} \mathrm{Bu}$ isnattaki râvilerden de Nasr b. Müzâhim (ö. 212/827-28), ${ }^{58}$ Dâvûd b. Ebû Avf ve Atıyye el-Avfî (ö. 111/729) ${ }^{59}$ Şî̀ eğilimler taşıdıkları gerekçesiyle eleştilmişlerdir. Bu rivayet diğerlerinin aksine ilgili sözün sürekli olarak tekrarlandığını ve aynı zamanda söylenme mekânını da barındırır.

Rivayet İbn Asâkir tarafından Ümmü Seleme'den nakledilir. “Ebü'l-Hasan Ali b. Müslim ve Ebü'l-Kāsım b. Semerkandî $\rightarrow$ Ebû Nasr İbn Tullâb $\rightarrow$ Ebü’lHüseyin b. Cümey' $\rightarrow$ Ebû Ca'fer Muhammed b. Ammâr b. Muhammed b. Âsım b. Mutî́ el-İclî $\rightarrow$ Muhammed b. Ubeyd b. Ebû Hârûn el-Mukrî $\rightarrow$ Ebû Hafs el-A ‘şâ $\rightarrow$ İsmâil b. Ebû Hâlid $\rightarrow$ Muhammed b. Sûka $\rightarrow$ mübhem $\rightarrow$ Ümmü Seleme" isnadıyla gelen rivayete göre Hz. Peygamber başını öne eğmiş vaziyette dururken Fâtıma onun için hazırladığı bir çorbayı getirir ve o esnada Hasan ile Hüseyin de yanındadır. Hz. Peygamber, kızına eşinin nerede olduğunu sorup onu da çağırmasını ister. Ali geldiğinde beraberce yemek yerler. Allah resulü sonrasında onları bir örtüyle sarar, örtünün bir ucunu sol eliyle tutar, sonra sağ elini gökyüzüne kaldırıp şöyle buyurur: "Allahım! Bunlar benim ehlibeytim ve yakın akrabalarımdır. Allahım! Onlardan kiri gider ve onları tertemiz kıl! Sizinle savaşanla savaşırım, sizinle barış içinde olanla barışık olurum, düşmanlık yaptığınıza da düşmanlık ederim!’"60 İbn Asâkir' in kaydettiği bir diğer isnat ise, “... Ebü’l-Abbas İbn Ukde $\rightarrow$ Abdullah b. Üsâme ve Ebû Şeybe $\rightarrow$ Ali b. Sâbit $\rightarrow$ Esbât b. Nusayr $\rightarrow$ Süddî $\rightarrow$ Bilâl b. Mirdâs $\rightarrow$ Şehr b. Havşeb $\rightarrow$ Ümmü Seleme" şeklindedir, ancak burada rivayetin ilgili bağlamı yer almaz. ${ }^{61}$

Sünnî eserlerde dört farklı sahâbîden gelse de genel olarak garîb sayılan bu rivayetin isnadındaki pek çok râvi dikkat çekici bir şekilde Şiî eğilimler taşıdığı gerekçesiyle eleştirilmiştir. İlgili hadisin Şiî halkalara intikali açısından Şiî eğilimli râviler iyi bir hareket noktası görünümündedir. Ancak bunun öncesinde rivayetin Şiî kaynaklardaki durumunu kronolojik olarak ortaya koymak, daha sonra da olası bağlam değişikliklerini ve bu eylemin tarzlarını ve sorumlularını tespit etmek gereklidir.

İlgili rivayetin izleri Şiî kaynaklara gelince sürüldüğünde Sünnî kaynaklardaki muhtasar rivayetlerin aksine, Hz. Peygamber'in Hz. Ali ve ailesine, "onlarla savaşanla savaşacağı, onlarla iyi geçinenlerle de iyi geçineceğini" bildiren ifadelerin uzun sayılabilecek anlatıların içerisinde yer aldığı görülür.

57 İbn Şâhin, Fezâilü Fâtıma, s. 31.

58 Ukaylî, ed-Duafầ, IV, 300; Hatîb, Târîh, XV, 383.

59 Cûzcânî, Ahvâlürr-ricâl, s. 56; İbn Kuteybe, el-Maârif, s. 518, 624; Zehebî, Siyer, V, 326.

6o İbn Asâkir, Târîh, XIV, 144.

61 İbn Asâkir, Târîh, XIII, 204. 
$\mathrm{Bu}$ durum ilgili rivayetin bağlam inşası türlerinden ikincisinin kapsamına girdiğini gösterir.

Mezkûr tablonun tek istisnası Tûsînin el-Emâlîsinde, "Ebül-Hasan Ahmed b. Muhammed b. Hârûn b. Salt el-Ehvâzî -[hicrî] 409'da- $\rightarrow$ Ahmed b. Muhammed b. Saîd İbn Ukde $\rightarrow$ İbrâhim b. Muhammed b. İshak b. Yezîd et-Tâî $\rightarrow$ İshak b. Yezîd $\rightarrow$ Sabbâh $\rightarrow$ Süddî $\rightarrow$ Subeyh $\rightarrow$ Zeyd b. Erkam" isnadıyla rivayet ettiği haberdir. Buna göre Zeyd b. Erkam şöyle demiştir: Allah resulü çıkmıştı, bir de baktı ki Ali, Fâtıma, Hasan ve Hüseyin [karşısındalar]! Bunun üzerine şöyle buyurdu: "Sizinle savaşanla savaşırım, sizinle barış içinde olanla da barışık olurum." 22 İsnatta vurgulu olarak gösterilen Süddî, Sünnî kaynaklarda da hadisi nakleden bir râvi konumundadır ve Şiî eğilimler taşımakla itham edilmiş biridir. Ancak İbn Ebû Şeybe, İbn Mâce ve Tirmizî rivayetlerine göre bilgiyi Süddîden alan kişi Esbât b. Nasr iken, Tûsî isnadında Sabbâh adlı bir râvinin yer aldığı görülür. Burada mutlak olarak sadece ismiyle anılan Sabbâhỉn, İbn Ebû Hâtim’in (ö. 327/938) verdiği hoca-talebe ilişkisi dikkate alındığında Ebû Muhammed Sabbâh b. Yahyâ elMüzenî el-Kûfî olduğu anlaşılmaktadır. ${ }^{63}$ Sabbâh, İbn Adîye göre Kûfe’nin Şî̂ râvilerindedi. ${ }^{64}$ Sünnî kaynaklarda çok fazla rivayeti bulunmayan Sabbâh, Şiî müelliflerce kitap sahibi sika bir râvi olarak anılır. ${ }^{65}$ Şu halde Sünnî kaynaklarda fazla tanınan bir isim olmamasına rağmen Şiî kaynaklarda övgüyle anılan Sabbâhỉn mezkûr rivayeti Şiî halkalara taşıdığı düşünülebilir. Ancak bu rivayet herhangi bir bağlam değişimi veya muhteva bakımından bir farklılık taşımaması hasebiyle sadece rivayet geçişkenliğini gösterebilir.

Sünnî kaynaklarda herhangi bir arka plan bilgisine yer verilmeksizin kaydedilen rivayetin Şiî kaynaklardaki diğer versiyonları incelendiğinde hadisin çok farklı isnatlarla ve uzun anlatıların içerisinde genellikle benzeri rivayetlerle terkip edilmiş olarak yer aldığı görülür. Rivayet Şiî kaynaklarda bazan Sünnî râvilerden müteşekkil bir isnatla gelirken bazan da Ehlibeyt isnadıyla kaydedilmiştir. Ancak her hâlükârda iki tip isnadın taşıdığı metinler de hayli hacimlidir ve türlü bağlamlara sahiptir. Şeyh Sadûk İbn Bâbeveyh'in (ö. 381/991), "Ahmed b. Ziyâd b. Ca'fer el-Hemdânî $\rightarrow$ Ali b. İbrahim b. Hâşim $\rightarrow$ Ca 'fer b. Seleme el-Ehvâzî $\rightarrow$ İbrâhim b. Muhammed es-Sekafî $\rightarrow$ İbrâhim b. Mûsâ İbn Uhti'l-Vâkıdî $\rightarrow$ Ebû Katâde el-Harrânî $\rightarrow$ Abdurrahman b. Alâ el-Hadramî $\rightarrow$ Saîd b. Müseyyeb" isnadıyla naklettiği rivayete göre İbn Abbas şöyle demiştir: "Allah resulü bir gün oturuyordu ve yanında Ali, Fâtıma,

62 Tûsî, el-Emâlî, s. 499.

63 İbn Ebû Hâtim, el-Cerh, IV, 442.

64 İbn Adî, el-Kâmil, V, 55.

65 Necâşî, er-Ricâl, s. 197; Tûsî, el-Fihrist, s. 85. 
Hasan ve Hüseyin vardı. Şöyle buyurdu: Allahım! Biliyorsun ki bunlar ehlibeytim ve insanların bana en seçkin gelenleri. Onları sevenleri sev, onlara kin güdenlere kin güt! Onlara dost olanlara dost, düşmanlık yapanlara düşman ol! Onlara yardım edene yardımcı ol! Onları her türlü kirden arındır ve her türlü günahtan berî kıl! Onları rûhu'l-kudüs ile destekle!” Rivayetin son tarafında Hz. Peygamber Hz. Ali’nin halife olacağını belirtip Hz. Fâtıma, Hasan, Hüseyin'i över ve şöyle buyurur: "Allahım! Seni şahit tutarım ki ben onları seveni severim. Onlara kin güdene kin güderim. Onlarla barış içinde olanla barışık olurum. Onlarla savaşana savaşçıyım. Onlara düşmanlık edene düşmanım. Onlara dost olana dostum." 66

İsnattaki râvilerden Saîd b. Müseyyeb (ö. 94/713), Abdurrahman b. Alâ el-Hadramî ve Ebû Katâde el-Harrânî (ö. 210/825) Sünnî ilim halkalarında rivayetleri bulunan ve Şiî eğilimlerinden söz edilmeyen râvilerdir. Ancak tâbiînden bir râvi olan Abdurrahman'inn ${ }^{67}$ bu isnatta İbnüll-Müseyyeb ile Ebû Katâde arasında yer alması tarihi bakımından mümkün olmadığı için isnat sorunludur. Bununla birlikte Sünnî kaynaklarda durumları netleştirilemeyen İbrâhim b. Mûsâ İbn Uhti'l-Vâkıdî el-Ensârî ve onun talebesi konumundaki İbrâhim b. Muhammed es-Sekafîye daha yakından bakılmalıdır.

Şiî kaynaklarda İbrâhim b. Mûsâ el-Ensârî olarak kaydedilen ve Ali erRızânın (ö. 203/819) ashabından olduğu belirtilen kişinin isnatta geçtiği üzere Vâkıdînin (ö. 207/823) yeğeni olduğuna dair herhangi bir bilgi yer almaz ancak bir kitabından bahsedilir. ${ }^{68}$ Hoca-talebe ilişkilerine dair bu tasvir kronolojik olarak doğru gibiyse de kesin bir yargıya varmak güçtür. Onun talebesi olan ve Kûfe'de doğsa da ilmî yaşantısını daha ziyade İsfahan'da sürdüren İbrâhim b. Muhammed b. Saîd es-Sekafî ise Sünnî âlimlerce Râfızî olduğu gerekçesiyle eleştirilmiş bir râvi olup 283 (896) senesinde vefat etmiştir. ${ }^{69}$ Şiî rical kaynaklarında övgüyle anılan râvinin pek çok kitabından bahsedilmektedir. ${ }^{70}$ İki ismin görüşmesinin tarihi bakımdan mümkün olması isnatta isimleri geçen râvilerin bu iki râvi olma ihtimalini kuvvetlendirir. $\mathrm{Bu}$ durumda eğer isnadın Sünnî râvilerin arka arkaya dizilmesiyle uydurulmuş bir isnat olmadığ düşünülecek olursa Ebû Katâde el-Harrânîye kadar Sünnî bir isnatla gelen rivayetin Şiî halkalara geçişinden sorumlu ismin İbrâhim b. Mûsâ olduğu söylenebilir. Öte yandan rivayetin ilk kısmı Sünnî kaynaklardaki haberlerle örtüşse de hadisin devamında Şiî öğretiyi desteleyecek ifadeler

66 İbn Bâbeveyh, el-Emâlî, s. 574.

67 İbn Hibbân, es-Sikāt, V, 100.

68 Necâşî, er-Ricâl, s. 27; Tûsî, Ricâl, s. 352; Tüsterî, Kāmûs, I, 304-305.

69 Ebü'ş-Şeyh, Tabâkāt, III, 350.

70 Necâşî, er-Ricâl, s. 19-20; Tûsî, el-Fihrist, s. 4-6; Tüsterî, Kāmîs, I, 275-80. 
yer alır. Bu durum ya Sünnî eserlerde ilgili kısmın hazfedildiği ve Şiî eğilimleri râvilerin ve dolayısıyla Şiî eserlerin rivayete tam olarak yer verdiği ya da rivayetin Şiî halkalara geçişinden sonra birtakım ilâvelere mâruz kaldığ şeklinde yorumlanabilir. Ancak Sünnî kaynakların tarihi bakımdan önceliği ve geçiş tabakasındaki râvilerin Şiî eğilimlerine dair söylenenler ve bu bilgilerin Şiî kaynaklarca da doğrulanması ikinci ihtimalin daha olası olduğunu düşündürür.

Şiî eserlerde rivayete Sünnî bir isnatla yer veren bir diğer müellif Tûsî̀dir. Onun ilgili ifadeyi farklı bir bağlama yerleştiren rivayetinin isnadı "Haffâr $\rightarrow$ Ebû Bekir Muhammed b. Ömer el-Ciâbî $\rightarrow$ Ebü'l-Hasan Ali b. Mûsâ el-Hazzâz $\rightarrow$ Hasan b. Ali el-Hâşimî $\rightarrow$ İsmâil b. Ebân $\rightarrow$ Ebû Meryem $\rightarrow$ Süveyr b. Ebû Fâhite $\rightarrow$ Abdurrahman b. Ebû Leylâ $\rightarrow$ babası" şeklindedir. İlgili rivayette Hayber'in fethinin Hz. Ali ile müyesser olduğu kaydedildikten sonra anlatı Gadîr Hum'daki hâdiseye getirilir ve Sünnî kaynaklarda farklı isnatlarla yaygın olarak yer alan "men küntü mevlâhu", "menzile", "ene harbün” vb. rivayetler art arda sıralanır. Sonrasında Hz. Peygamber'in ağladığ 1 , buna sebep olarak da Cibril'in kendisine Alìye ve onun evlatlarına zulmedileceğini bu durumun kâimin gelişine değin süreceğini haber verdiğini söyler. ${ }^{71} \mathrm{Bu}$ anlatıya göre "ene harbün..." rivayeti Gadîr-i Hum'da fezâil içerikli pek çok haberle birlikte söylenmiş ve sonrasında da birtakım gaybî ihbarlara yer verilmiştir. İlk olarak Tûsî isnadına bakıldığında Abdurrahman b. Ebû Leylâ (ö. 83/702), ${ }^{72}$ Ebüll-Cehm Süveyr b. Ebû Fâhite (ö. 127/744), ${ }^{73}$ Ebû Meryem Abdülgaffâr b. Kāsım el-Kûfî (ö. 160/777’lerde) ${ }^{74}$ ve Ebû İshak İsmâil b. Ebân el-Verrâk’’n (ö. 216/831) ${ }^{75}$ Şiî eğilimlere sahip olmakla itham edildikleri görülür. Muhammed Bâkır el-Meclisî (ö. 1111/1699) ise bu rivayeti kaydederken, "Osman b. Ahmed [İbnü’s-Semmâk] [ö. 344/955] $\rightarrow$ Ebû Kılâbe [ö. 276/889] $\rightarrow$ Bişr b. Ömer [ö. 207/823] $\rightarrow$ Mâlik b. Enes $\rightarrow$ Zeyd b. Eslem..." şeklindeki isnadı da Tûsî isnadıyla birlikte verir. ${ }^{76}$ Halbuki bu isnat Tûsî tarafından kaydedilmediği gibi isnattaki râviler de bu tarz bir rivayeti nakletmesi imkân dahilinde olmayan kimselerdir ve içlerinden hiçbirinin Şî̂ eğilimlerinden söz edilmemiştir. Şu haliyle rivayetin isnadından hareketle bilginin Şiî kaynaklara geçiş dönemi hakkında bir şey söylemek zorsa da,

71 Tûsî, el-Emâlî, s. 524-26.

72 İclî, Ma'rifetü's-sikät, I, 480; Hatîb, Târîh, XI, 457.

73 Ka'bî, Kabûlü̉l-ahbâr, II, 401; Ukaylî, ed-Duafầ, I, 180; Şehristânî, el-Milel, I, 190.

74 İbn Ebû Hâtim, el-Cerh, VI, 530; İbn Hibbân, el-Mecrûhîn, II, 143; İbn Adî, el-Kâmil, VI, 338-40.

75 Cûzcânî, Ahvâlürr-ricâl, s. 84; Zehebî, Siyer, X, 348; İbn Hacer, Takrîb, s. 105. 76 Meclisî, Bihârü̉l-envâr, XXVIII, 45. 
muhtemelen farklı isnatların ve metinlerin terkibiyle oluşturulan uzun anlatıda "ene harbün..." rivayeti de yepyeni bir bağlama kavuşmaktadır.

Yine Tûsînin kaydettiği başka bir isnat da Sünnî râvilerden müteşekkildir. Onun "cemâa $\rightarrow$ Ebü'l-Mufaddal [Muhammed b. Abdullah eş-Şeybânî] $\rightarrow$ Hasan b. Muhammed b. Şu'be el-Ensârî $\rightarrow$ Ebü’s-Saîb Selm b. Cünâde $\rightarrow$ Vekî‘ b. Cerrâh $\rightarrow$ Süfyân b. Saîd es-Sevrî $\rightarrow$ Câbir b. Yezîd el-Cu fô" isnadiyla rivayet ettiğine göre Abdullah b. Yahyâ el-Hadramî, Hz. Alỉnin şöyle dediğini işitmiştir: “(Bir gün) Hz. Peygamber'in yanındaydık. O uyuyordu, başı kucağımdaydı. Deccalden bahsettik. O esnada Hz. Peygamber yüzü kızarmış olarak uyandı ve şöyle buyurdu: Sizin adınıza deccalden daha fazla endişelendiğim bazı şeyler var: Saptırıcı önderler ve benden sonra itretimin kanının dökülmesi. Ben onlarla savaşanla savaşırım. Onlarla barış içinde olan benimle de barışık olur."77

Görüldüğü üzere bu rivayetin bağlamı diğerlerinden daha farklıdır. Şöyle ki: Bir grup sahâbînin sohbetine uyandıktan sonra iştirak eden Hz. Peygamber gaybî nitelikli birtakım bildirimlerde bulunur ve "ene harbün..." diyerek kendisini Ehlibeyt düşmanlarının karşısında konumlandırır. İsnattaki râvilerden Şiîliği hakkında en çok konuşulan isim Câbir el-Cúfîdir. Süfyân es-Sevrî (ö. $161 / 778)^{78}$ ve Vekî́ b. Cerrâh (ö. 197/812) $)^{79}$ hakkındaki Şiîlik ithamları ciddiye alınabilecek bir mahiyet arzetmediği gibi Selm b. Cünâde ile (ö. 254/867) ilgili bir tenkit de söz konusu değildir. Bununla birlikte Sünnî kaynaklarda kendisinden neredeyse hiç bahsedilmeyen Abdullah b. Yahyâ, Şiî kaynaklara göre Hz. Ali’nin yakın ashabı olarak bilinen şurtatü'l-hamîstendir. ${ }^{80}$ Normal şartlarda bu bilginin Şiî halkalara intikalinin Abdullah b. Yahyâ veya Câbir el-Cu'fì eliyle olması ihtimalinden bahsedilebilecekken, bu isimlerden sonra naklin yine Şiî olmayan râvilerle sonraki nesillere ulaşması bu ihtimali zayıflatmaktadır. İsnattan anlaşıldığı kadarıyla bu rivayet onu Selm'den alan Hasan b. Muhammed b. Şu'be'den sonra yani III. (IX.) asrın ikinci yarısında Şiî halkalara geçmiştir.

Rivayet Şiî kaynaklarda Şiî isnatlarla da kayıtlıdır ve bu rivayetlerde, "ene harbün..." kısmı genellikle uzunca bir anlatının içerisinde yer alır. Yukarıda temas edilen Sünnî isnatlı ilk Tûsî rivayetinde olduğu gibi mürekkep rivayet havası veren bu metinlerden biri Şeyh Sadûk İbn Bâbeveyh tarafından "Ca'fer b. Muhammed b. Mesrûr $\rightarrow$ Muhammed b. Abdullah b. Ca'fer b.

77 Tûsî, el-Emâlî, s. 754 .

78 İbn Kuteybe, el-Maârif, s. 624.

79 Yahyâ b. Maîn, et-Târîh (Dûrî), III, 359; İbn Kuteybe, el-Maârif, s. 624 .

8o Berkî, er-Ricâl, s. 3 . 
Câmi` el-Himyerî $\rightarrow$ babası $\rightarrow$ Ya'kūb b. Yezîd $\rightarrow$ Hasan b. Ali b. Faddâl $\rightarrow$ Ebü'l-Hasan Ali b. Mûsâ er-Rızâ $\rightarrow$ babası $\rightarrow$ ataları" isnadıyla tahriç edilmiştir. Herhangi bir bağlam bilgisi barındırmayan rivayete göre Allah resulü şöyle buyurmuştur: "Ali bendendir, ben de Ali'denim. Ali ile savaşını Allah katletsin, Aliye muhalefet edene Allah lânet etsin. Ondan ayrı düşen benden ayrı düşmüştür. Ona üstün gelmeye çalışan bana üstün gelmeye çalışır. Onunla barış içinde olan benimle barışıktır, onunla savaşanla ben de savaşırım. Ona dost olan dostum, ona düşmanlık eden düşmanım." ${ }^{81}$ Bu isnat Ali er-Rızâyya Ehlibeyt imamları vasıtasıyla ulaşırken, ondan sonra normal rivayet yollarıyla yani Ehlibeyt'e mensup olmayan râviler aracılığı ile nakledilmiştir. Rivayetin ilk kısmındaki, "Ali bendendir, ben Ali'denim" ile sonundaki, "Ona dost olan dostum, ona düşmanlık eden düşmanım" ifadeleri müstakil rivayet olarak nakledilmiştir. Ancak burada "ene harbün..." ifadesiyle diğer sözler tek bir seferde söylenmiş gibi sunulmaktadır.

Rivayetin Şiî isnatlı diğer versiyonları Şeyh Müfìd tarafından nakledilir. Onun "Ebû Ca'fer Muhammed b. Ali b. Hüseyin $\rightarrow$ babası $\rightarrow$ Muhammed b. Yahyâ el-Attâr $\rightarrow$ Ahmed b. Muhammed b. Îsâ $\rightarrow$ Ali b. Hakem $\rightarrow$ Hişâm b. Sâlim $\rightarrow$ Süleyman b. Hâlid $\rightarrow$ Ebû Abdullah Ca'fer b. Muhammed es-Sâdık $\rightarrow$ ataları" isnadıyla rivayet ettiğine göre Allah resulü, Ali’ye, "Ali! Sen bendensin, ben sendenim. Senin dostun bana ve Allah'a dosttur. Senin düşmanın ise benim ve Allahı̉n düşmanıdır. Ali! Seninle savaşana ben de savaşçıyım, seninle barış içinde olanla da barışık olurum" buyurup onun için cennette hazırlanan bazı nimetlerden söz etmiştir. Rivayetin devamındaki, "Ali! Cennet ve cehennemin kriteri sensin. Cennete ancak seni tanıyan ve senin tanıdığın girer, cehenneme ancak seni inkâr eden ve senin inkâr ettiğin girer. Ali! Sen ve evlatlârından olan imamlar kıyamet günü arafta olacaks1nız. Mücrimler simalarından, müminler alâmetlerinden tanınacak. Ali! Sen olmasan müminler benden sonra [doğruyu] bilemezlerdi" gibi ifadeler de, ilk kısımda olduğu gibi mürekkep bir rivayet intibaı vermektedir. ${ }^{82}$ Burada rivayetin normal nakil üslûbuna döndüğü yer Ca'fer es-Sâdık'tır (ö. 148/765). Zira haberi ondan bir imam değil, Süleyman adlı râvi almıştır. Her hâlükârda "en harbün..." rivayeti uzun bir anlatının içerisinde ve yeni bir siyak-sibak ile kendisine yer bulmuştur.

Şeyh Müfîd'in naklettiği diğer haber ise muhteva bakımından öteki rivayetlerden farklılık arzeder. "Muhammed b. Ali $\rightarrow$ amcası Muhammed b. Ebü'l-Kāsım $\rightarrow$ Ahmed b. Muhammed b. Hâlid $\rightarrow$ İbn Ebû Necrân $\rightarrow$ Alâ $\rightarrow$ Muhammed b. Müslim $\rightarrow$ Ebû Ca'fer Muhammed b. Ali el-Bâkır $\rightarrow$ Câbir 
b. Abdullah" isnadiyla gelen ve bu haliyle bir imamin siradan birinden yani Bâkır'ın Câbir'den naklini gösteren bu haber ${ }^{83}$ Câbir ile Hz. Peygamber'in bir diyalogunu içerir. Bu konuşmada Hz. Peygamber'in sırasıyla Selmân elFârisî, Ebû Zer, Mikdâd ve Ammâr hakkındaki övücü ifadelerine yer verilir, ardından Câbir de, "Sen de bizdensin. Allah sana kin güdene kin güder, seni seveni sever" hitabına mazhar olur. Konu Hz. Ali olunca Hz. Peygamber, “O, canımdır" buyurur. Hasan, Hüseyin ve anneleri için, "Onlar ruhumdur, anneleri Fâtıma kızımdır. Ona kötülük yapan bana kötülük yapmıştır. Onu sevindiren beni sevindirmiştir. Allah’’ şahit tutarım ki onlarla savaşanla savaşırım. Onlarla barış içinde olanla da barışık olurum" der. Son olarak Câbir'e, Allah'a dua edip de duasının makbul olmasını istediğinde Allah'a onların isimleriyle dua etmesi salık verilir. ${ }^{84}$

Burada "ene harbün..." rivayeti hakkında genel bir değerlendirme yapmak uygun olacaktır. Anlaşılacağı üzere Sünnî eserlerde haber genellikle herhangi bir arka plan bilgisi barındırmaz. Bu nakillere göre Hz. Peygamber bir vesile ile Ehlibeyt mensuplarının yanında olduğunu ifade etmiştir. Bunun tek istisnası sözün vürut bağlamına dair İbn Şâhin'in kaydettiği daha muahhar bir rivayettir. Ancak burada da sadece sözün söylenme yeri ve zamanı hakkında birtakım bilgiler yer alır.

İlgi çekici bir şekilde Sünnî isnatlardaki pek çok râvi Şiî eğilimler taş1dıkları gerekçesiyle eleştirilmişlerdir. Şiî kaynaklara başvurulduğunda ise rivayetin hem Sünnî hem de Şiî isnatlarla kaydedildiği görülür. Her iki isnat grubunda da mürekkep rivayet olduğu düşünülebilecek metinler bulunmaktadır. Ancak Tûsînin kaydettiği bir Sünnî isnat rivayetin Şiî halkalara geçişini sağlayan isimlerden birinin, Sünnî kaynaklarda da bu haberin râvisi olan Süddînin öğrencisi Sabbâh olduğunu düşündürmektedir. Kaydedilen bir Sünnî isnada göre ise haberi Şiî halkalara intikal ettiren isim Vâkıdînin yeğeni olduğu belirtilen İbrâhim b. Mûsâ gibidir. Şiî isnatlarda geçişkenlik meselesi takip edilemiyorsa da Ehlibeyt imamlarından gelen haberlerin bir süre sonra mâsum imamlar tarafından değil de sıradan râviler aracılığı ile aktarıldığı söylenebilir. Bu durum ise Şiî rivayet ve cerh-ta'dîl tarihi açısından önem arzeder. Zira bu aşamadan sonra bilgi imamların ardından gelen ve hata etme ihtimalleri bulunan râviler eliyle sonraki nesillere ulaşacaktır. Ancak bu çalışma açısından daha önemli olan nokta, "ene harbün..." ifadesinin neredeyse bütün Şiî isnatlı rivayetlerde uzun bir anlatının içerisinde yer alıyor oluşudur.

83 Bu isnat kalıbıyla ilgili olarak bk. Kohlberg, "An Unusual Shīī Isnād", s. 142-49. 84 Müfîd, el-İhtisâs, s. 217-18. 


\section{C) Ali'nin Kapısı}

Sünnî kaynaklarda farklı sahâbîlerden nakille yer alan muteber bir habere göre Hz. Peygamber, Hz. Ali’nin mescide açılan kapısı haricindeki kapıların kapatılmasını emretmiş, bazı tariklerde bunun gerekçesi sahâbîler tarafından sorulduğunda bu uygulamanın vahye dayandığını bildirmiştir. Zeyd $b$. Erkam, İbn Abbas, Câbir b. Semüre (ö. 70/690'dan sonra), Berâ b. Âzib (ö. 71/690[?]), Abdullah b. Ömer (ö. 73/692) ve Câbir b. Abdullah’in (ö. 78/697) yanı sıra bu rivayet Sa'd b. Ebû Vakkās (ö. 55/675) tarafından da nakledilir. ${ }^{85}$ Burada, Şiî kaynaklardaki serüveni de takip edilebileceği için rivayetin Sa'd tarikine yoğunlaşlacaktır. Nitekim Ahmed b. Hanbel'in "Haccâc $\rightarrow$ Fitr $\rightarrow$ Abdullah b. Şerîk” isnadıyla tahriç ettiğine göre Abdullah b. Rukaym elKinânî şöyle demiştir:

Cemel zamanında Medine’ye gittik ve orada Sa'd b. Mâlik ile karşılaştık. O bize, "Allah resulü mescitteki açık kapıların kapatılmasını emretti, ancak Ali’nin kapısını bunun dışında bıraktı" dedi. ${ }^{86}$

Görüldüğü üzere Cemel Savaşı rivayetin gündeme geldiği süreçte oldukça sıcak bir gündem maddesidir ve Sa'd'ın Kûfe'den gelen bir grup insana bu rivayeti herhangi bir bağlama yer vermeden nakletmesi, Ali’nin faziletini gündeme getirmek çerçevesinde anlaşılmalıdır. Kapı kapama eyleminin vahiyle irtibatının kurulmadığı bu rivayete mukabil İbn Ebû Âsım’n, "Hasan b. Ali $\rightarrow$ Yezîd b. Hârûn $\rightarrow$ Fitr $\rightarrow$ Abdullah b. Şerîk" isnadıyla naklettiğine göre Abdullah b. Erkam şöyle demiştir:

Bir grup insanla Kûfe'den Medine’ye geldik. Sa'd b. Ebû Vakkās ile karşılaştık, "Iraklı olsanız, Iraklı olsanız" dedi. Ona en yakın yerdeki kişi bendim. Ali’yi sorup, "Onu gördünüz mü? Benden bahsettiğini duydunuz mu?" dedi. Biz "Onu görmedik, senin ismini de işitmedik. Ama onu 'Saptırıc1nın [ahnes] fitnesinden sakının' derken duyduk" dedik. Sa 'd "Benim adımı andı mı?" deyince "Hayır" cevabını verdik. Sad "Saptırıcı çok. Ne var ki ben Allah resulünden şu üç şeyi işittikten sonra Aliyi hep seveceğim: [1.] Allah resulü, Ebû Bekir'i Berâe sûresiyle yolladı, ardından Ali'yi gönderdi ve Ali sûreyi ondan ald. Ebû Bekir ise öfkesini içine atarak dönüp '[Ama] Allah’nn resulü!' dedi. Bunun üzerine Hz. Peygamber, 'Benim adıma ancak benden olan bir kişi emaneti iletebilir' buyurdu. [2.] Ali dışında mescidin yanındaki kimselerin kapıları kapatıldı. Abbas 'Allah’n resulü! Kapılarımızı kapattın, en gencimiz olduğu halde Ali’nin kapısını ise bunun dışında tuttun' dedi. Bunun üzerine Allah resulü, 'Onu orada ben bırakmadım,

85 İlgili rivayetler ve değerlendirmesi için bk. Akcaoğlu, Hz. Peygamber'in Kur'ân Vahyi

Dışında Bilgilendirilmesi, s. 514-22.

86 Ahmed b. Hanbel, el-Müsned, III, 98-99. 
kapılarınızı da ben kapatmadım. Ancak bu bana emredildi' buyurdu. [3.] Tebük Seferi’nde, 'Nezdimdeki konumunun Mûsâ yanındaki Hârun gibi olmasına razı değil misin? Ne var ki sen peygamber değilsin' buyurdu." ${ }^{87}$

Görüldüğ̈̈ üzere isnat belli bir noktaya kadar Ahmed isnadı ile aynısa da rivayet daha farklı ayrıntılar içerir. Abdullah b. Rukaym ile Abdullah b. Erkam aynı kişidir. Dolayısıyla iki isnat tamamen aynıdır. Sadece Ahmed ile İbn Ebû Âsım’ın hocaları farklıdır ki, bu da normal bir durumdur.

Nesâînin (ö. 303/915) “Ahmed b. Yahyâ $\rightarrow$ Ali b. Kādim $\rightarrow$ İsrâîl $\rightarrow$ Abdullah b. Şerîk" isnadıyla naklettiğine göre ise Hâris b. Mâlik şöyle demiştir:

Mekke’ye geldim ve Sa'd b. Ebû Vakkās ile karşılaşınca ona, "Ali ile ilgili bir menkıbe işittin mi?” diye sordum. Şu cevabı verdi: Allah resulü ile mescitte idik. Gecenin bir vaktinde Allah resulünün ailesi ve Ali’nin ailesi dışındakilerin mescitten çıkmaları duyuruldu. Biz de çıktık. Sabah olduğunda Hz. Peygamber'in amcası (Abbas) gelip, “Allah’n resulü! Ashabını ve amcalarını çıkarttın, şu çocuğu ise orada bıraktın” dedi. Bunun üzerine Allah resulü şöyle buyurdu: "Benim herhangi birinizin çıkmasını ve bu çocuğun orada kalmasını [kendiliğimden] emretmem mümkün değil. Bunu emreden Allah'tır."

Nesâî bu rivayetin ardından Fitr b. Halîfe’nin (ö. 153/770), “Abdullah b. Şerîk $\rightarrow$ Abdullah b. Rukaym $\rightarrow$ Sa'd" isnadıyla naklettiği habere göre ise Abbas'ın (ö. 32/653) Hz. Peygamber’e gelip, “Ali’nin kapısı hariç kapılarımızı kapattın” dediğini, buna cevaben Allah resulünün, "Ben [kendiliğimden] açmadım da kapatmadım da" buyurduğunu bildirir. ${ }^{88}$

Nesâ̂̉nin yer verdiği Fitr rivayeti, Ahmed b. Hanbel'in naklinin aksine ilgili uygulamayı vahye dayandırmaktadır. Bu durum Abdullah b. Şerîk ve Fıtr'in rivayeti farklı zamanlarda farklı şekillerde naklettiği veya rivayeti onlardan alan isimlerin metinde birtakım tasarruflara gittiği şeklinde yorumlanabilir. Öte yandan Ahmed b. Hanbel ve Nesâî rivayetleri gibi Fitr tarikiyle gelen İbn Ebû Âsım metni, diğer iki metne göre hayli uzundur ve hem Hz. Ali hakkında daha fazla fazilet verisi ile kapı kapama emrinin vahye müstenit olduğunu hem de rivayetin dile getirilme zamanını içerir. Ancak her hâlükârda bu isnat zincirlerinde yer alan Abdullah b. Şerîk, ${ }^{89}$ Fitr b Halîfe ${ }^{90}$ ve Ali b.

87 İbn Ebû Âsım, es-Sünne, II, 917-18.

88 Nesâî, es-Sünenü'l-kübrâ, V, 118. Râvi adı Tahâvî metninde "Ebî” ziyadesiyle "Abdullah b.

Ebû Rukaym” şeklinde kaydedilir (Şerhu müşkiliłl-âsâr, IX, 185).

89 Cûzcânî, Ahvâlürr-ricâl, s. 49; İbn Ebû Hâtim, el-Cerh, V, 80-81; İbn Hibbân, el-Mecrûhîn, I, 519 .

90 Ahmed b. Hanbel, el-İlel, II, 338; İclî, Ma'rifetü's-sikāt, II, 208; İbn Kuteybe, el-Maârif, s. 624 . 
Kādim (ö. 213/828) Şiî eğilimler taşıdığ gerekçesiyle eleştirilen râvilerdir. ${ }^{91}$ İbn Ebû Âsım isnadında Abdullah b. Erkam diye kaydedilen isim ise aslında meçhul bir râvi olarak görülen Abdullah b. Rukaym b. Erkam'dır. Yani burada râvinin babasının adı düşürülmüş, onun yerine dedesinin adı anılmıştır.

Taberânînin "Ali b. Saîd er-Râzî $\rightarrow$ Süveyd b. Saîd $\rightarrow$ Muâviye b. Meysere b. Şüreyh $\rightarrow$ Hakem b. Uteybe" isnadiyla naklettiğine göre Mus'ab b. Sa'd (ö. 103/721), babası Sa'd’ın şöyle dediğini söyler:

Allah resulü, Alỉnin kapısı dışındaki kapıların kapatılmasını emretti. "Allah’n resulü! Ali’nin kapısı dışındaki bütün kapıları kapattırdın" dediklerinde o, "Kapılarınızı ben kapattırmadım. Fakat onları Allah Teâlâ kapattırdı" buyurdu. ${ }^{92}$

İlgili faaliyetin gayr-i metlüv vahiyle yapıldığını bildiren bu rivayetin isnadında da Hakem Şî̂ eğilimli olmakla tenkit edilmiştir. ${ }^{93}$

Sonuç olarak Sünnî kaynaklarda Hâris b. Mâlik, Abdullah b. Rukaym ve Musáb b. Sa'd vasitasiyla Sa'd b. Ebû Vakkās'tan nakledilen haber, İbn Ebû Âsım rivayeti istisna edilecek olursa etraflı bir arka plan bilgisi içermez. Rivayetlerdeki ihtilâflı nokta ise kapıyı kapatma eyleminin vahye müstenit olup olmadığıdır.

Rivayet Şiî kaynaklarda ise oldukça farklı bir isnat ve çoğu Sünnî metinden farklı ancak İbn Ebû Âsım metnine yakın bir bağlamla sunulur. Tûsînin, "Muhammed b. Muhammed $\rightarrow$ Ebü'l-Hasan Ali b. Mâlik en-Nahvî $\rightarrow$ Ebü’lHasan Ahmed b. Ali el-Muaddel $\rightarrow$ Osman b. Saîd $\rightarrow$ Muhammed b. Süleyman el-İsfahânî $\rightarrow$ Ömer b. Kays el-Mekkî” isnadıyla naklettiğine göre İbn Abbas'in âzatlısı İkrime (ö. 105/723) şöyle demiştir:

Muâviye haccedip Medine’ye geldiğinde Sadd b. Ebû Vakkāsin onun yanına girmesi için izin talep edildi. Muâviye yanındakilere, "Sa'd’a izin verince gelip oturduğunda Ali b. Ebû Tâlib'den söz etmeye başlayın" dedi. Ardından ona izin verdi, o da gelip yaygının üzerine oturdu. Bir grup, emîrü'l-mü’minîne hakaret etti. Sa'd’ın gözleri yaşlarla doldu. Muâviye ona, "Niye ağlıyorsun Sa'd? Kardeşin Osman b. Affân’ın katiline hakaret edilmesine mi ağlıyorsun?” dedi. Bunun üzerine Sa'd şu cevabı verdi: Vallahi ağlamaya engel olamıyorum. Biz Mekke'den muhacir olarak çıkmıs, bu mescide -Mescid-i Resûl'ü kastediyor- gelmiştik. Gündüz-gece orada istirahat ederdik. Biz oradan çıkarıldık, Ali ise bırakıldı. Bu bize ağır geldi. Ancak Allahin peygamberine bunu söylemekten çekindik. Âişe’ye gidip

91 İbn Sa'd, et-Tabakāt, VI, 404; İbn Hacer, Takrîb, s. 404.

92 Taberânî, el-Mu'cemü'l-evsat, III, 82.

93 İclî, Ma'rifetüs-sikāt, I, 312-3; İbn Kuteybe, el-Maârif, s. 624. 
ona, "Müminlerin annesi! Biz de Ali gibi sahâbîyiz, biz de onun gibi hicret ettik. Ne var ki biz mescitten çıkarıldık, o ise bırakıldı. Bu Allah'tan gelen bir kızgınlıktan mı, yoksa resulünden gelen bir öfkeden mi bilemedik. Bu durumu ona söylesen ya. Zira biz ondan çekiniyoruz" dedik. Âişe bunu Allah resulüne söylediğinde o cevaben, Âiş̧e! Vallahi hayır! Onları ben çıkarmadım. Ali'yi de ben oraya yerleştirmedim. Allah onları çıkardı, Ali’yi bıraktı' buyurdu." Biz Hayber seferine katıldık. Orada hezimete uğrayanlar oldu. Bunun üzerine Allah’n peygamberi, "Bugün sancağı, Allah’ ve resulünü seven, Allah ve resulünün de kendisini sevdiği birine vereceğim” buyurdu ve Ali’yi çağırdı. O, gözünden rahatsızdı. Hz. Peygamber onun gözüne tükürügünü sürdü, sancağı ona verdi ve fetih müyesser oldu. Allah resulü ile Tebük Seferi’ne katıldık. Ali, Hz. Peygamber'e veda edip ağladı. Hz. Peygamber ona, "Niçin ağlıyorsun?" diye sorduğunda, "Nasıl ağlamayayım! Allah seni nübüvvetle gönderdiğinden beri hiçbir savaşta seninle bulunmaktan geri kalmadım. Niçin beni bu seferden geri bırakıyorsun ki!” dedi. Bunun üzerine Allah resulü, “Ali! Nezdimdeki konumunun Mûsâ yanındaki Hârun gibi olmasına razı değil misin? Ne var ki benden sonra peygamber yok!” buyurdu. Ali de, “Tamam, razıyım” cevabinı verdi. 94

Tûsînin naklettiği bu haber muhtevası açısından özellikle İbn Ebû Âsım rivayetini çağrıştırıyorsa da, rivayetin söylenme sebebi açısından Sünnî rivayetlerden oldukça farklıdır. Rivayete göre Muâviye b. Ebû Süfyân (ö. 60/680), sanki Sa'd'ı incitmek adına Hz. Ali'ye hakaret edilmesini temin etmektedir. Hem söz konusu hakaretler hem de Muâviye'nin Hz. Ali'yi, “Osman'ın katili” olarak anması, Sa'd'ı Ali'nin faziletine dair birtakım haberleri aktarmaya itmiş gibidir. Rivayette dikkat çeken ikinci nokta, kapıların kapanmasından duyulan rahatsızlığı Hz. Peygamber'e ileten ismin, Sünnî kaynaklarda olduğu gibi Abbas değil, Hz. Âişe (ö. 58/678) olmasıdır. Sünnî haberlerde Sa'd’ın zikrettiği bir menkıbe Berâe sûresinin bildirilmesiyle ilgili iken burada Hayber Gazvesi gündeme gelmektedir. Muâviye ile Sa'd arasındaki bu hadisenin iki kere gerçekleşmiş olma ihtimalinden bahsedilebilirse de anlatının çoğu öğesinin benzeşmesi aynı hadisenin farklı suretlerde nakledildiğini düşündürür.

Rivayetin isnadındaki isimlere daha yakından bakıldı̆̆ında İkrime ve Ömer b. Kays el-Mekkî hakkında birtakım bilgilere Sünnî kaynaklarda tesadüf edilir. Ayrıca bu isimlerin Şiî eğilimlerinden bahsedilmez. Rivayetin Sünnî ders halkalarından Şî̂ halkalara intikalini temin eden isim ise muhtemelen Ebû Ali Muhammed b. Süleyman b. Abdullah el-İsfahânî el-Kûfî̀dir

Tûsî, el-Emâlî, s. 267-68. 
(ö. 181/797). Sünnî kaynakların herhangi bir Şiî eğiliminden bahsetmediği Muhammed b. Süleyman Şiî kaynaklarda İmam Sâdık'tan nakilde bulunan güvenilir bir râvi konumundadır. ${ }^{95}$ Ebü'l-Hasan Ahmed b. Ali el-Muaddel ve Osman b. Saîd'in ${ }^{96}$ kimliklerini netleştirmek mümkün olmamışsa da, Ebü’lHasan Ali b. Mâlik en-Nahvî Şiî bir râvidir.

Tûsînin "Ebü'l-Mufaddal $\rightarrow$ Muhammed b. Hârûn b. Humeyd İbnüllMücedder $\rightarrow$ Muhammed b. Humeyd er-Râzî $\rightarrow$ Cerîr ve Eşsas b. İshak $\rightarrow$ Ca 'fer b. Ebü’l-Mugīre $\rightarrow$ Saîd b. Cübeyr" isnadıyla kaydettiği ikinci rivayete göre İbn Abbas şöyle demiştir:

Zûtüvầya indiği zaman Muâviye’nin yanındaydım. Sa'd b. Ebû Vakkās gelip ona selâm verdi. Muâviye, "Şamlılar! Bu Sa'd [b. Ebû] Vakkās'tır. Ali’nin arkadaşıdır" dedi. Bunun üzerine topluluk başlarını sallayıp Ali'ye hakaret ettiler. Sa'd da ağladı. Muâviye ona, "Seni ağlatan ne?" diye sorunca Sa'd şöyle dedi: "Nasıl ağlamayayım! Allah resulünün ashabından birine senin yanında hakaret ediliyor ve ben bu durumu değiştiremiyorum. Alide birtakım hasletler vardı ki, onlardan sadece birinin bende olması bana dünya ve içindekilerden daha hoş gelir..."

Rivayetin devamında Sa'd, Hz. Ali’nin şu beş özelliğini zikreder: Hz. Ali’nin eleştirilmesine mukabil dile getirilen "men küntü mevlâhu" rivayeti, Hayber Gazvesi’nde sancağın Hz. Alìye verilmesi, "menzile hadisi”, sadece son kısmılla ve vahye atıf yapılmadan verilen "kapıların kapatılması hadisi" ve tathir âyetinin uygulama alanı olarak Ehlibeyt'i tespit eden rivayet. ${ }^{97}$ Tûsînin sevkettiği isnattaki Saîd b. Cübeyr (ö. 94/713[?]), Ca'fer b. Ebü’lMugìre, Cerîr b. Abdülhamîd (ö. 188/803), Eşas b. İshak, Muhammed b. Humeyd er-Râzî (ö. 248/862) ve İbnü’l-Mücedder (ö. 312/924) Sünnî rical kaynaklarında kendilerine yer verilen râvilerdir. Bu isimlerden sadece Cerîr Şiî eğilimler taşımakla itham edilmiştir. ${ }^{98}$ Cerîr'den musannife kadarki kısımda da Sünnî râvilerin yer alıyor oluşu, rivayetin bu tarikinin Cerîr tarafından Şiî halkalara intikali ihtimalini zayıflatmaktadır. Bu tarikin geçişi hayli geç bir dönemde, IV. (X.) asrın başlarında ve muhtemelen Tûsînin hocası tabakasında vuku bulmuştur. Geçişkenlikten sorumlu râvinin tespit edilemeyişi bağlam farklılığının izahını da zorlaştırmaktadır. İlk Tûsî rivayetindeki bağlam değişimi II. (VIII.) asra tarihlenebilir görünüyorsa da, ikinci rivayet için böyle bir durum söz konusu değildir. Şiî kaynaklarda rivayet İkrime ve İbn Abbas’tan gelirken, Sünnî kaynaklarda bu isimler söz konusu hadisin

95 Necâşî, er-Ricâl, s. 351; Tûsî, Ricâl, s. 283.

96 Hûî, bu Osman’n geçtiğini düşündügü isnatları verir (Mu'cem, XII, 121-22).

97 Tûsî, el-Emâlî, s. 861-62.

98 İbn Kuteybe, el-Maârif, s. 624; İbn Hacer, Tehzîlb, II, 65. 
râvisi olarak görünmezler. Sünnî tariklerin aksine her iki Tûsî rivayetinde de Muâviye'nin mezkûr rivayetin naklindeki olumsuz rolü açıktır. Bu durum akla, ashap hakkındaki birtakım olumsuzluklar içeren bu rivayetlerin Sünnî muhaddislerce dikkate alınmamış olabileceği ihtimalini de getirmektedir. $\mathrm{Bu}$ ihtimal kabul edildiğinde ise Şiî râvi veya müelliflerce yapılan bir bağlam değişimi veya inşası faaliyetinden değil, Sünnî musanniflerin kısmî bir sansüründen bahsedilmek durumundadır. Ancak bu ihtimali destekleyecek ilâve bir bilgi tespit edilememiştir.

\section{Anlam Kaymaları}

Bağlam inşası çerçevesinde değerlendirilebilecek ikinci bir faaliyet Sünnî kaynaklarda yer alan anlatının kendisinin aynen aktarılmasına mukabil ona yüklenen anlamın yepyeni bir çerçeveye kavuşturulabilmesidir. Anlam kayması olarak nitelenebilecek bu faaliyeti gösteren rivayetlere iki örnek verilecek, her bir örnekte hem rivayeti Şiî halkalara taşıyan kimseler hem de yorumun muhtemel sorumlusu tespit edilmeye çalışlacaktır.

\section{A) “On İki Halife...” Rivayeti}

Sünnî kaynaklarda geçen "Kureyş içerisinden on iki halife/emîrin çıkacağı”na dair hadis türlü yorumlara konu olmuşsa da âlimler sadra şifa bir yorum üzerinde ittifak edememiştir. Çok ufak tasarruflarla Şiî kaynaklarda da geçen bu haber İmâmiyye Şîası̀nın itikadî bir esas olarak kabul ettiği imam sayısıyla mutabakat arzettiğinden özellikle imâmet teorisinin nihaî halini aldığı III. (IX.) asrın sonlarından itibaren ciddi bir ilgiye mazhar olmuş ve hem Ehl-i sünnet'e karşı itikadî pozisyonu tahkim eden hem de imamların sayısına dair farklı Şiî fraksiyonlara cevap veren bir delil olarak görülmüştür. Bazı geç Şiî anlatılarda rivayet taktî́ ile yeni bir bağlama yerleştirilmiş veya farklı bir bağlam inşası ile sunulmuşsa da bu rivayette söz konusu husus bir bağlam inşasından ziyade yorumun farklı bir bağlama kaydırılmasıdır. Dolayısıyla burada bağlam inşasının sorumluları yerine, rivayetin Şiî halkalara geçiş döneminin ve bu geçişi sağlayan râvilerin tespit edilmesi daha uygun olacaktır.

Sünnî kaynaklarda daha ziyade Câbir b. Semüre tarafından nakledilen rivayet Abdullah b. Mes'ûd (ö. 32/652-53), Abdullah b. Amr (ö. 65/684-85), Abdullah b. Ömer ve Ebû Cuhayféden de (ö. 74/693-94) gelir. Yaygın ve güvenilir bir isnat ağına sahip olan rivayetler arasındaki metin farklılıkları da 
dikkat çekici bir boyutta değildir. Ancak hadisin tariklerinde halife kelimesi yerine emîr, nakip veya racül kelimesi geçer. ${ }^{99}$

Rivayetleri bir arada zikrettiği için burada esas alınabilecek Müslim b. Haccâc (ö. 261/875), hadisi "Kuteybe b. Saîd $\rightarrow$ Cerîr $\rightarrow$ Husayn $\rightarrow$ Câbir b. Semüre" isnadıyla nakletmiştir. Buna göre Câbir şöyle demiştir: ${ }^{100}$ Babamla birlikte Hz. Peygamber' in yanına girdik. Onun, "Bu iş, içlerinden on iki halife gelinceye kadar kesintiye uğramayacaktır" buyurduğunu işittim. Bunun ardından anlayamadığım bir şey daha söyledi. Babama, "Ne dedi?" diye sorduğumda, "Tamamı Kureyş̧ten dedi” cevabını verdi. ${ }^{101}$ Müslim’in sevkettiği isnatlardaki râvilerden Şa bî (ö. 104/722) ${ }^{102}$ ve Cerîr b. Abdülhamîd Şiî eğilimler taşıdıkları gerekçesiyle eleştirilmişse de bu ithamların rivayetin Şiî halkalarındaki yayılımıyla herhangi bir ilgisinin olduğunu söylemek hayli zordur.

Şî̂ imâmet teorisinin nihaî hali ile örtüşür bir şekilde on iki halife/ emîrden bahseden Câbir b. Semüre rivayetinin erken dönem Şiî eserlerinde yer almadığı görülür. Ancak IV. (X.) asrın ikinci yarısından sonra rivayet Şiî müelliflerce sıklıkla kullanılmış ve on iki sayısının Hz. Peygamber tarafından belirlenmiş olması hem Sünnî muhataplara hem de imâmeti daha düşük sayılarda durduran ayrılıkçı Şiî cemaatlere karşı bir delil olarak gündeme gelmiştir. ${ }^{103}$

Hadisin farklı tariklerine eserinde yer veren ${ }^{104}$ ve "Sünnîler' in hadisi Câbir b. Semüre'den meşhur olarak naklettiklerini” söyleyen Şeyh Sadûk’un, "Ahmed b. Hasan el-Kattân $\rightarrow$ Ebû Bekir Ahmed b. Muhammed b. Abdürab-

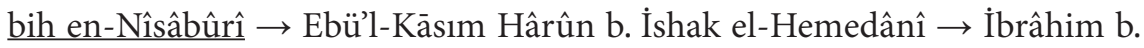
Muhammed $\rightarrow$ Ziyâd b. İlâka ve Abdülmelik b. Umeyr $\rightarrow$ Câbir", "Ahmed b. Hasan el-Kattân $\rightarrow$ Ebû Ali Muhammed b. Ali b. İsmâil el-Mervezî $\rightarrow$ Sehl b. Ammâr en-Nîsâbûrî $\rightarrow$ Amr b. Abdullah b. Rezîn $\rightarrow$ Süfyân $\rightarrow$ Saîd b. Amr $\rightarrow$ Şa"bî $\rightarrow$ Câbir", 105 "Ahmed b. Muhammed b. İshak ed-Dîneverî $\rightarrow$ Ebû

99 Rivayet hakkında etraflı bilgi için bk. İmamoğlu, Hadis ve Siyaset, s. 354-405.

100 Müslim'in kaydettiğine göre Husayn dışında Abdülmelik b. Umeyr, Simâk, Şa ‘bî ve Âmir b. Sa'd b. Ebû Vakkās da hadisi Câbir'den nakletmiştir.

101 Müslim, "İmâre", 5-10.

102 İbn Sa'd, et-Tabakāt, VI, 248 (Burada onun sonradan mezkûr görüşten döndüğü kayıtlıdır); Şehristânî, el-Milel, I, 190.

103 Şiî imâmet teorisinin gelişim süreciyle ilgili olarak bk. Kohlberg, "From Imāmiyya to Isnā 'Ashariyya”, s. 521-534; Bozan, İmâmiye’nin İmâmet Nazariyesinin Teşekkül Süreci; Büyükkara, Ehl-i Beyt, s. 217-45.

104 İbn Bâbeveyh, Kemâlü'd-dîn, s. 68, 270-71, 271, 279 (zikredilen yerlerde İbn Mes'ûd tarikleri vardır).

105 İbn Bâbeveyh, Kemâlü'd-dîn, s. 272. 
Bekir b. Ebû Dâvûd $\rightarrow$ İshak b. İbrâhim b. Şâzân $\rightarrow$ Velîd b. Hişâm $\rightarrow$ Muhammed b. Zekvân $\rightarrow$ babam $\rightarrow$ babası $\rightarrow$ İbn Sîrîn $\rightarrow$ Câbir b. Semüre", 106 "Abdullah b. Muhammed es-Sâiğ $\rightarrow$ Ebü'l-Hüseyin Ahmed b. Muhammed


Velîd el-Basrî $\rightarrow$ İsrâil $\rightarrow$ Simâk $\rightarrow$ Câbir"107 ve "Abdullah b. Muhammed $\rightarrow$ Ebüll-Hüseyin Ahmed b. Muhammed b. Yahyâ el-Kasrânî $\rightarrow$ Ebû Ali Hüseyin b. Kümeyt b. Bühlûl el-Mevsilî $\rightarrow$ Gassân b. Rebî $\rightarrow$ Süleyman b. Abdullah -Âmir eş-Şa ‘bînnin âzatlısı- $\rightarrow$ Şa cbî $\rightarrow$ Câbir" şeklinde verdiği isnatlar ${ }^{108}$ Müslim'in isnatlarıyla neredeyse tamamen örtüşür.

Şeyh Sadûk isnatlarında altı çizili isimlere kadarki râviler ilmî yaşantılarını ehl-i hadis çevresinde sürdürmüş ve genellikle Şiî eğilimlerinden söz edilmeyen isimlerdir. Altı çizili râvilerin biyografisine ise Sünnî kaynaklarda ya hiç yer verilmez ya da haklarında oldukça kısa bilgiler sunulur. Bu durumda altı çizili râvilerin, ilgili rivayeti Sünnî hocalarından alıp Şiî ilim çevrelerine taşıdıkları söylenebilir.

Bu dönemde rivayete yer veren bir diğer müellif Ebü'l-Kāsım el-Hazzâz'dır (IV./X. asır). Şeyh Sadûk'taki bazı isnatlara bir râvi ile ulaşan Hazzâz, ${ }^{109}$ rivayete "Muhammed b. Ali $\rightarrow$ Ahmed b. Hasan el-Kattân $\rightarrow$ Ebû Ali Muhammed b. Ali b. İsmâil $\rightarrow$ Fazl b. Abdülcebbâr el-Mervezî $\rightarrow$ Ali b. Hasan b. Şakìk $\rightarrow$ Hüseyin b. Vâkıd $\rightarrow$ Simâk b. Harb $\rightarrow$ Câbir b. Semüre"110 "Ahmed

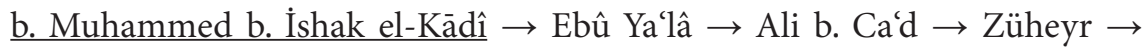
Ziyâd b. Hayseme $\rightarrow$ Esved el-Hemdânî $\rightarrow$ Câbir b. Semüre" isnadıyla da yer verir. ${ }^{111}$ Rivayetin Şiî kaynaklara intikalinde muhtemelen altı çizili isimler etkili olmuştur. Çünkü isnadın bu isimlere kadarki kısmındaki râvilerin Şiî yapılarla herhangi bir ilişkisi bulunmamaktadır. İlginç bir şekilde hem Sadûk hem de Hazzâz isnatlarında diğer Sünnî-Şiî rivayet geçişkenliklerinin aksine ya III. (IX.) asrın sonları ya da IV. (X.) asrın başlarında yaşamış râvilerin merkezde olduğu görülür. Bu durum yukarıda işaret edildiği üzere söz konusu rivayetlerin imâmet teorisinin nihaî halini almasıyla önem kazanmasından kaynaklanmıştır. İbn Ebû Zeyneb en-Nưmânî (ö. 360/971) $)^{112}$

106 İbn Bâbeveyh, Kemâlü'd-dîn, s. 272-73.

107 İbn Bâbeveyh, Kemâlü'd-dîn, s. 273.

108 İbn Bâbeveyh, Kemâlü'd-dîn, s. 273-74.

109 Hazzâz, Kifâyetü'l-eser, s. 109-11.

110 Hazzâz, Kifâyetü'l-eser, s. 111.

111 Hazzâz, Kifâyetü'l-eser, s. 112.

112 Nu'mânî, el-Gaybe, s. 104-109 (burada sekiz rivayete yer verir); 117-25 (burada yirmi dört rivayete yer verir). 
ve Tûsînin ${ }^{113}$ de hadisi büyük oranda Sünnî isnatlarla zikretmeleri aynı durumun net birer göstergesidir.

Aslına bakılırsa genel olarak on iki imam rivayetlerinin tarihî süreçte mâruz kaldığı müdahaleler, Şiî itikadının gelişim evreleri hakkında oldukça müdellel veriler sunmaktadır. Nitekim Abbâd b. Ya'kūb el-Usfûrînin (ö. 255/868) el-Asl’ındaki "on bir nakib"in Küleynî (ö. 329/941) metninde on ikiye çıkması bu durumun tipik bir örneğidir. ${ }^{114}$ Her hâlükârda imam sayısının on iki olduğuna dair genel bir kabulün bulunmadığg bir dönemde, ilgili rivayetlerin Şiî çevrelerce nakledilmesini beklemek pek mâkul değildir. Ancak bu kabulün yerleşmesinin ardından rivayet hem Sünnîlere hem de son imamın varlığından şüphe duyan ya da imam sayısını daha erken bir dönemde sonlandıran Şiî cemaatlere bir cevap niteliği arzetmiştir. Öte yandan Şî̀ kaynaklardaki yorumların metnin içerdiği asıl kavram olan "halife" kelimesine rağmen yapıldığı da dikkate alınmalıdır. Şiî imamların hiçbir zaman halife olmadıkları dikkate alındığında Şiî müellifler ya halife kavramını tevil ederek ya da bu kelimenin aslında "imam" iken farklı bir şekilde nakledildiğini söyleyerek izah etmek durumundadırlar.

\section{B) “Allah Yüzünü Ak Etsin!” Rivayeti}

Muteber Sünnî kaynaklarda hadislerin sonraki nesillere aktarılmasını teşvik bağlamında sıklıkla zikredilen bir rivayete göre Hz. Peygamber, "Allah, sözlerimi işitip kavrayan ve (duyduğu şekilde) başkalarına aktaran kimsenin yüzünü ak etsin! İnsanlar! Burada olanlar olmayanlara bildirsin. Zira bilgi taşıyan bazı kişiler vardır ki iyi kavrayışlı değildir. Bilgi taşıyan bazı kimseler vardır ki, onu kendisinden daha kavrayışlı birine ulaştırır" buyurmuştur. ${ }^{115}$ Bu haliyle muhtasar olarak zikredilen rivayetin bazı tariklerinde, "Üç şey var ki müslümanın kalbi onlarla dolu olduğunda aldanmaz: Amelin samimi bir şekilde Allah için yapılması, müslümanların idarecilerine karşı samimi olmak ve müslümanların cemaatine (siyasî birlik) yapışmak. Nitekim onların çağrısı diğerlerini de bağlar. Müslümanlar, kanları eşit olan kardeşlerdir ve onlar başkalarına karşı tek bir yumruktur. En alt mertebedeki müslümanın verdiği teminat dahi geçerlidir" ifadeleri de yer alır. ${ }^{116}$ İster tam isterse muhtasar haliyle rivayetin herhangi bir Şiî cemaati desteklemesi mümkün

113 Tûsî, el-Gaybe, s. 127-28, 130-31.

114 Kuzudişli, Şîa ve Hadis, s. 255-57.

115 Ahmed b. Hanbel, el-Müsned, VII, 221; Ebû Dâvûd, "İlim", 10; Tirmizî, "İlm”, 7; İbn Mâce, "Mukaddime", 18.

116 Ahmed b. Hanbel, el-Müsned, XXI, 6o; XXVII, 300-301, 318; XXXV, 467; Tirmizî, "İlim", 7; İbn Mâce, "Mukaddime", 18. 
gözükmese de Küleynînin el-Kâfîsinde yer alan bir haber, rivayete yüklenen anlam hakkında fikir vermektedir.

Küleynî, Usûlü̉l-Kâfîsinde, "Muhammed b. Hasan $\rightarrow$ ba'du ashâbinâ $\rightarrow$ Ali b. Hakem $\rightarrow$ Hakem b. Miskîn” isnadiyla yer alan rivayete göre Mekkeliler'den Kureyşli biri şöyle demiştir:

Süfyân es-Sevrî, "Haydi Ca'fer b. Muhammed’e gidelim" dedi. Onunla birlikte Ca'fer'in yanına gittik ve onu bineğine binmek üzere iken bulduk. Süfyân ona, "Bize Allah resulünün Hayf Mescidinndeki hutbesini nakletsene!" dedi. O, "Bırak da gidip işimi halledeyim. Şimdi bineğe bindim, gidip gelince naklederim" cevabını verdi. Süfyân es-Sevrî, "Allah resulüne yakınlığın aşkına bana bunu nakletmeni rica ediyorum" dedi. Bunun üzerine Ca'fer bineğinden indi. Süfyân es-Sevrî, "Benim için mürekkep ve kâğıt istesen de kaydetsem" demesine üzerine bunları getirtti ve "Yaz bakalım" dedi. "Rahman ve rahim olan Allahın adıyla. Allah resulünün Hayf Mescidinndeki hutbesi (şöyledir): Allah, sözlerimi işitip kavrayan ve başkalarına aktaran kimsenin yüzünü ak etsin! İnsanlar! Burada olanlar olmayanlara bildirsin. Zira bilgi taşıyan bazıları vardır ki iyi kavrayışılı değildir. Bilgi taşıyan bazı kimseler vardır ki, onu kendisinden daha kavrayışlı birine ulaştırır. Üç şey var ki müslümanın kalbi onlarla dolu olduğunda aldanmaz: Amelin samimi bir şekilde Allah için yapılması, müslümanların idarecilerine karşı samimi olmak ve müslümaların cemaatine yapışmak. Nitekim onların çağrısı diğerlerini de bağlar. Müslümanlar, kanları eşit olan kardeşlerdir ve onlar başkalarına karşı tek bir yumruktur. En alt mertebedeki müslümanın verdiği teminat dahi geçerlidir."

Süfyân es-Sevrî bunu yazdı, sonra da oradan ayrıldı, Ebû Abdullah da [Ca'fer es-Sâdık] bineğine bindi. Ben ve Süfyân gittik. Yolun belli bir yerine gelince, "Bir dur da şu hadise bakayım" dedi. Ona, "Ebû Abdullah seni öyle bir bağladı ki kıpırdama imkânın yok" dedim. O, "Bunu nasıl yaptı da?" diye sorunca ona, "Üç şey var ki müslümanın kalbi onlarla dolu olduğunda aldanmaz" ifadesindeki "Amelin samimi bir şekilde Allah için yapılması"nı anladık. Peki, "müslümanların idarecilerine karşı samimi olmak" ifadesindeki "Samimi olmanın bize borç olduğu müslümanların idarecileri kim? Muâviye b. Ebû Süfyân, Yezîd b. Muâviye ve Mervân b. Hakem mi? Her biri bizim nezdimizde şehâdeti ve arkalarında namaz kılınması câiz olmayan bu kişiler mi? 'Onların cemaatine tutunmak' ifadesindeki cemaat kimler? Namaz kilmayan, oruç tutmayan, cünüplükten dolayı gusül almayan, Kâbe’yi yıkan, annesiyle nikâhlanan, sonra da (imanı) Cebrâil ve Mîkâil'in imanı gibi olan Mürciî mi? Yoksa 'Allah’̉n istediği olmaz, İblis'in istediği olur' diyen Kaderî mi? Ya da Ali b. Ebû Tâlib’den teberrî edip onun kâfir olduğuna şahitlik yapan Harûrî mi? Yahut 'İman 
Allah’ı tek olarak bilmektir, bunun dışında iman esası yoktur' diyen Cehmî mi?" diye sordum. O, "Yapma ya! Peki, onlar [yani Şiî cemaatler] ne diyorlar?" dedi. Ben de, "Onlar 'Ali b. Ebû Tâlib, desteklenmesi boynumuza borç olan imamdır, cemaatlerine yapışılacak cemaat ise Ehlibeyt'tir' diyor" cevabını verdim. Bunun üzerine (rivayeti yazdığı) kâğıdı alıp yırttı, sonra da "Bunu kimseye söyleme!" dedi. ${ }^{117}$

Rivayet Küleynî tarafından "Udde min ashâbinâ $\rightarrow$ Ahmed b. Muhammed b. Îsâ $\rightarrow$ Ahmed b. Muhammed b. Ebû Nasr $\rightarrow$ Ebân b. Osman $\rightarrow$ İbn Ebû Ya fûr $\rightarrow$ Sâdık $\rightarrow$ Allah resulü" isnadı ile de ancak bağlamsız olarak kaydedilmiştir. ${ }^{118}$ Şiî hadis usulü açısından Caffer es-Sâdık ile Hz. Peygamber arasındaki râvilerin hazfedilmiş olması herhangi bir sorun teşkil etmez. Bilginin Ca'fer es-Sâdık'tan sonraki aktarımı ise mâsum imamlardan müteşekkil Ehlibeyt isnadı ile değil, sıradan râviler aracılığı ile temin edilmiştir. Söz konusu isimlerin Şiî cerh-ta 'dîl anlayışı açısından problemsiz oldukları görülür. Küleynînin kullandığı ve etrafında birtakım tartışmaların döndüğü "udde" tabirinin ${ }^{119}$ ise onun yaşadığı dönemde çok da sorun teşkil etmediği söylenebilir.

Hadisenin gerçekleştiği zaman aralığının tespiti, rivayet keyfiyeti hakkında birtakım sorunların giderilmesine imkân verebilir. Öncelikle hem Süfyân es-Sevrînnin Hicaz bölgesine ilk gelişinin 124-126 (742-744) yılları arasında olduğu tahmini ${ }^{120}$ hem de onun zaman zaman bilgi aldığ 1 ismi gizleyen âlimlerden olduğu dikkate alınırsa bu tarihte isnadın tam bir halinin talep edilmeyip Ca'fer es-Sâdık’n nakliyle yetinilmesi normal görülebilir. Tabii ki tarihle ilgili ihtimale, Süfyân’n daha birçok defa Hicaz bölgesine gidip geldiği gerekçesiyle itiraz edilebilir. Ancak onun babasının vefatının ardından (kuvvetle muhtemelen 126 [744]) ilmî faaliyetlerini daha ziyade Kûfe'de sürdürdüğü, ömrünün son yıllarını Basra'da kaçak olarak yaşadığı bilinmektedir. Rivayette en azından herhangi bir Abbâsî halifesinin adının anılmaması, söz konusu diyalog gerçekleştiğinde henüz Abbâsî devriminin (132/749) yapılmadığı izlenimini vermektedir. İlginç bir şekilde rivayet Sünnî kaynaklarda hayli yaygın bir isnat ağı ile gelmesine rağmen, hicrî ilk üç asır metinlerinde yer alan isnatların hiçbirinde Ca'fer es-Sâdık ve Süfyân es-Sevrînin adı anılmaz. ${ }^{121} \mathrm{Bu}$ durum, Süfyân es-Sevrînin muhtemelen ken-

117 Küleynî, Usûl, s. 469-7o.

118 Küleynî, Usûl, s. 468.

119 Kuzudişli, Şîa ve Hadis, s. 447-51.

120 Özdirek - Çavuşoğlu, "Süfyân es-Sevrî”, s. 23.

121 İsnadında Sevrînin yer aldığı bir rivayet muahhar bir kaynak olan İbn Asâkir'in Târîh'inde yer alır (LI, 212). Burada Süfyân es-Sevrînin ilgili hadisi muhtasar olarak Abdülmelik b. Umeyr'den naklettiği görülür. Ancak daha erken metinlerde hadisi Abdülmelik’ten aktaran ismin Sevrî değil İbn Uyeyne olduğu (örnek olmak üzere bk. Humeydî, el-Müsned, I, 47) olması İbn Asâkir isnadının hatalı olduğunu düşündürür. 
disine yüklenen itikadî ve siyasî anlamdan dolayı hadisi nakletmediğine yorulup ilgili hadisenin gerçekleşmiş olma ihtimalini kuvvetlendiren bir karine olarak görülebilir.

Öte yandan Sünnî isnatlardaki râviler gözden geçirildiğinde bir iki istisna dışında ciddi olarak Şiîlik ithamına mâruz kalan herhangi bir râviye de tesadüf edilmez. İstisna isimlerden biri, rivayetleri Halîfe b. Hayyât'nn (ö. 240/854-55) hadislerinin derlenmesiyle oluşturulan Müsned'de yer alan ${ }^{122}$ Ebû Hamza Sâbit b. Dînâr es-Sümâlîdir (ö. 148/765). Bu ismin Şiî rical kaynaklarında hem Bâkır'ın hem de Ca'fer es-Sâdık'in talebesi olarak kaydedildiği görülür. ${ }^{123}$ Aldığı kaynağı tasrih etmese de Ca'fer es-Sâdık bu nakli ya ataları vasıtasıyla ya da hocaları tabakasında olup rivayetin Sünnî isnatlarında isimleri geçen Muhammed b. Cübeyr b. Mut'im (ö. 100/718), Ebân b. Osman (ö. 105/723), İbn Şihâb ez-Zührî (ö. 124/741) aracıllğ̆1 ile elde etmiş olabilir. Ancak bu noktada bilginin Şiî eğilimli râvi Ebû Hamza es-Sümâlî ile Şiî halkalara geçmiş olma ihtimali de akılda tutulmalıdır. Bu ihtimali kuvvetlendiren bir kayıt ise Alâ b. Rezîn'in Asl’nnda rivayetin Ebû Hamza tarafından Ebû Ca'fer Muhammed el-Bâkır'dan -muhtasar olarak- nakledilmesidir. ${ }^{124}$ Ancak her hâlükârda Şiî kaynaklar rivayetin Bâkır veya Sâdık'tan Hz. Peygamber’e kadarki silsilesi hakkında bilgi sunmaz.

Sonuç olarak "Allah yüzünü ak etsin!" rivayeti bağlam değişimi ve inşasından ziyade anlam kaymasıyla Şiî kaynaklara geçen bir haber olarak görülmelidir. Hadise yüklenen anlamın değişiminden ise kuvvetle muhtemel Ca'fer es-Sâdık ya da onun tavrından hareketle böyle bir çıkarımda bulunan ve adı tasrih edilmeyen "Mekkeli zat" sorumlu olsa gerektir.

\section{Sonuç}

II. (VIII.) asrın sonlarından itibaren farklılaşan Sünnî-Şiî ilim gelenekleri incelenirken tek başına ilmî âmiller değil Şî̉nın sınırlı bir cemaat yapısından mezhebe evrilme aşamaları ve bunu tetikleyen sosyoekonomik etkenler, cemaatin değişen bölgesel konumu, özellikle Ca'fer es-Sâdık ve sonrasındaki imamların cemaate kimlik kazandırma politikaları ve Sünnî siyasanın Şiî azınlıklara bakışı gibi pek çok husus da dikkate alınmak durumundadır. Bu hususların rivayet geçişkenlikleri ve olası uydurma faaliyetleri ya da bağlam değişimleri ile eş zamanlı okunabilmesi ise erken devir ilim geleneği açısından büyük önem arzetmektedir. Sınırlı bir çerçevede

122 Halîfe b. Hayyât, Müsned, s. 47.

123 Tûsî, Ricâl, s. 129, 174.

124 el-Usûlüss-sitte aşer, s. 363. 
bu hususların bir kısmını dikkate alarak bağlam değişimlerine ve bunların sorumlularına dikkat çekmeyi hedefleyen bu makalede, Sünnî bir rivayetin Şiî halkalara geçiş sürecinde birtakım tasarruflara mâruz kaldığ 1 görülmüştür.

Değişen bağlamlardan sorumlu râvi kümesinin tespitindeki en dakik hareket noktası, bir râvinin hem Sünnî hem de Şiî kaynaklarda ilgili rivayetin nâkili olarak görülmesi, buna ilâveten Şiî isnatlarda kendisinden müellife kadarki aktarımı yapan isimlerin Sünnî kaynaklarda müstakil olarak yani özel başlıklar altında ele alınmamış olmasıdır. Zira özellikle II. (VIII.) asırdan sonra Şî̀ isnatlarda yer alan râviler çoğu zaman Sünnî kaynaklarda tespit edilememektedir. Bu durumda ilgili râvinin, rivayeti Şiî halkalara taşıdığı ve rivayetin belli bir dönemden sonra Sünnî halkalardan bağımsız ilim yapma becerisini elde eden Şiî halkalarda sonraki nesillere aktarıldığı düşünülecektir. Büyük oranda Kûfeli olan Şiî eğilimli râviler hakkındaki bu tespitin yapılması sadece bilgi geçişkenliğini değil, bağlam değişimlerini anlama imkânı da verebilir. İlgili bağlamın yeniden inşası ihtimalinden söz etmeden önce, rivayetin Sünnî kaynaklardaki farklı tariklerinin tamamı gözden geçirilmek durumundadır. Çünkü bazı tâli Sünnî kaynaklarda bu tarz rivayetlerin fark1 bağlamlarla yer almasına mukabil, rivayet diğer bazı müelliflerce ihtisar ve taktî̀ gibi işlemlerle daha sorunsuz olarak nakledilebilmektedir. Ayrıca Ehl-i sünnet kaynaklarındaki bağlamsız bir rivayete Şiîlik'le itham edilmiş bir râvi tarafından bağlam eklenebilmesi ihtimali de dikkate alınmalıdır. Her hâlükârda isnattaki râvilere yoğunlaşılmalı ve değișen bağlamın Şiî telakkileri doğrulama tarzı ele alınmalıdır.

Bağlam değişimi faaliyetlerinin, rivayetin anlam tarihi açısından irat ve musannif bağlamlarıyla ilgili olduğu ileri sürülebilir. Ancak burada hadislerin söylenme sebeplerini ifade eden irat bağlamının sadece sahâbe değil, daha sonraki tabakaları da içerdiğinin altı çizilmelidir. Muhtemelen bazı râviler elde ettikleri rivayetleri şahsî mezhebî temayülleri dolayısıyla farklı bağlamlara taşıyabilmişlerdir. Dikkat çekici bir şekilde değişen bağlamlar veya yeni anlamlar yüklenen rivayetler bazan $\mathrm{Hz}$. Ali ve Şiî düşünceyi daha yüksek bir konuma çıkarmakta bazan da Hz. Ali ve Ehlibeyt muhaliflerini daha kötü göstermektedir. Özellikle polemik tarzı rivayetlerdeki geçişkenlikler ve bağlam değişimleri hakkında tekdüze bir çalışma planının uygulanması ve dönem belirlemesinin yapılması mümkün görünmemektedir. $\mathrm{Bu}$ noktada her bir rivayet müstakil olarak ele alınmalı, çözümlenen isnatlardaki Şiî eğilimli râvilerden hareketle bağlam değişimlerinin yönü ve değişen bağlamların kimi ne şekilde desteklediği tarihî çerçeve dikkate alınarak sunulmalidir. 


\section{Bibliyografya}

Ahmed b. Hanbel, el-İlel ve ma'rifetürr-ricâl, nşr. Vasiyyullah b. Muhammed Abbas, I-IV, Riyad: Dârü'l-Hânî, 1422/2001.

Ahmed b. Hanbel, Müsnedül-İmâm Ahmed b. Hanbel, nşr. Şuayb el-Arnaût v.dğr., I-LII, Beyrut: er-Risâletü'l-âlemiyye, 1436/2015.

Ahmed b. Hanbel, Fezâilüss-sahâbe, nşr. Vasiyyullah b. Muhammed Abbas, I-II, Mekke: Câmiatü Ümmi'l-kurâ, 1403/1983.

Ahmed b. Hanbel, Suâlâtü Ebî Bekr el-Esrem li'l-İmâmi'l-kebîr Ebî Abdillâh Ahmed b. Muhammed b. Hanbel fi'l-cerh ve't-ta'dîl ve ileli'l-hadîs, nşr. Ebû Ömer Muhammed b. Ali el-Ezherî, Kahire: el-Fârûku'l-hadîse li't-tıbâa ve’n-neşr, 1428/2007.

Akcaoğlu, Faik, Hz. Peygamber'in Kur'ân Vahyi Dışında Bilgilendirilmesi (doktora tezi), Marmara Üniversitesi, 2010.

Aynî, Bedreddin, Megāni’l-ahyâr fî şerhi esâmî ricâli Meâni'l-âsâr, nşr. M. Hasan M. Hasan İsmâil, I-III, Beyrut: Dârü'l-kütübi'l-ilmiyye 1427/2006.

Belâzürî, Ensâbü'l-eşrâf, nşr. Süheyl Zekkâr - Riyâz Ziriklî, I-XIII, Beyrut: Dârü'l-fikr, $1417 / 1996$.

Berkī, er-Ricâl, Tahran: İntişârât-i Dânişgâh-i Tahrân, ts.

Bezzâr, el-Bahrüz-zehhâr: el-Müsned, nşr. Mahfûzurrahman Zeynullah v.dğr., I-XVIII, Medîne: Mektebetü'l-ulûm ve'l-hikem, 1408-30/1988-2009.

Bozan, Metin, İmâmiye’nin İmâmet Nazariyesinin Teşekkül Süreci, İstanbul: İSAM, 2009.

Buhârî, Muhammed b. İsmâil, et-Târîhu'l-kebîr, I-IX, Beyrut: Dârü'l-kütübi'l-ilmiyye, ts. Büyükkara, Mehmet Ali, Ehl-i Beyt ve Ehl-i Devlet: Musa Kâzım ile Ali Rızâ Dönemi Şî̀liği ve Abbasiler, İstanbul: İFAV, 2010.

Ca'fer el-Huldî, el-Fevâid ve'z-zühd ve’r-rekāik ve'l-merâsî, nşr. Mecdî Fethî es-Seyyid, Tanta: Dârü's-sahâbe li’t-türâs, 1409/1989.

Cûzcânî, Ebû İshak, Ahvâlürr-ricâl, nşr. Subhî el-Bedrî es-Sâmerrâî, Beyrut: Müessesetü’rrisâle, 1405/1985.

Ebû Dâvûd es-Sicistânî, Sünenü Ebî Dâvûd, nşr. Şuayb el-Arnaût - M. Kâmil Karabellî, I-VII, Beyrut: er-Risâletü'l-âlemiyye, 1433/2012.

Ebû Dâvûd es-Sicistânî, Suâlâtü Ebî Ubeydillâh el-Âcurrî li'l-İmâm Ebî Dâvûd Süleymân b. el-Eş'as es-Sicistânî fì ma'rifetìr-ricâl ve cerhihim ve ta'dîlihim, nşr. Ebû Ömer Muhammed b. Ali el-Ezherî, Kahire: el-Fârûku'l-hadîse li’t-tıbâa ve’n-neşr, 1431/2010.

Ebû Ya'lâ el-Mevsılî, el-Müsned, nşr. Hüseyin Selîm Esed, I-XIV, Dımaşk: Dârü’l-Me’mûn li’t-türâs, 1410/1990.

Ebü’ş-Şeyh, Tabâkātü'l-muhaddisîn bi-İsbahân ve'l-vâridîne aleyhâ, nşr. Abdülgafûr Abdülhak Hüseyin el-Belûşî, I-IV, Beyrut: Müessesetürr-risâle, 1412/1992.

Fesevî, el-Ma'rife ve’t-târîh, nşr. Ekrem Ziyâ el-Ömerî, I-IV, Medine: Mektebetü'd-dâr, $1410 / 1989$.

Görmez, Mehmet, Sünnet ve Hadisin Anlaşılması ve Yorumlanmasında Metodoloji Sorunu, Ankara: OTTO, 2014.

Hâkim en-Nîsâbûrî, el-Müstedrek, I-IV, Haydarâbâd: Dârü'l-kütübi'l-ilmiyye, 1334-42. 
Halîfe b. Hayyât, Müsned, nşr. Ekrem Ziyâ el-Ömerî, Beyrut: eş-Şeriketü’l-müttehide, 1405/1985.

Hatîb el-Bağdâdî, Târîhu medîneti's-selâm ve ahbâru muhaddisîhâ ve zikru kuttâniha'lulemâ min gayri ehlihâ ve vâridîhâ, nşr. Beşşâr Avvâd Ma'rûf, I-XVII, Tunus: Dâru'lgarbi'l-İslâmî, 1436/2015.

Hazzâz, Ebü'l-Kāsım Ali b. Muhammed, Kifâyetül-eser fin-nusûs ale’l-eimmeti'l-isnâ aşer, nşr. M. Kâzım el-Mûsevî - Akīl er-Rebîî, Kum: Merkezü Nûri'l-envâr fî ihyâi Bihâri'l-envâr, 1387/1430.

Hûî, Ebü'l-Kāsım, Mu'cemü'r-ricâlil-hadîs ve tafsîlü tabakātír-ruvât, I-XXIV, Necef: Mektebetü'l-İmâm el-Hûî, ts.

Humeydî, Abdullah b. Zübeyr, el-Müsned, nşr. Habîbürrahman el-A'zamî, I-II, Beyrut Kahire: Dârü'l-kütübi'l-ilmiyye - Mektebetü’l-Mütenebbî, ts.

İbn Adî, el-Kâmil fî duafâir r-ricâl, nşr. M. Enes Mustafa el-Hın, I-IX, Beyrut: er-Risâletü’lâlemiyye, 1433/2012.

İbn Asâkir, Ebü’l-Kāsım, Târîhu medîneti Dımaşk, nşr. Muhibüddin Ebû Saîd Ömer b. Garâme el-Amrî, I-LXXX, Beyrut: Dârü'l-fikr, 1415-21/1995-2001.

İbn Bâbeveyh, Şeyh Sadûk, el-Emâlî, Kum: Müessesetü'l-bi'se, 1417.

İbn Bâbeveyh, Şeyh Sadûk, Kemâlü̉d-dîn ve temâmün-ni'me, nşr. Ali Ekber el-Gaffârî, Kum: Müessesetü’n-neşri'l-İslâmî, 1363/1405.

İbn Ebû Âsım, Kitâbü̉s-Sünne, nşr. Bâsim b. Faysal el-Cevâbire, I-II, Riyad: Dârü’s-sumay î, $1419 / 1998$.

İbn Ebû Hâtim, el-Cerh ve't-ta'dîl, I-IX, Haydarâbâd: Dâiretü'l-maârifi'l-Osmâniyye, 1371-73/1952-53.

İbn Ebû Şeybe, el-Musannef, nşr. M. Avvâme, I-XXVI, Beyrut: Dâru Kurtuba, 1427/2006.

İbn Hacer el-Askalânî, Tehzîbü't-Tehzîb, I-XIV, Beyrut: Dârü’l-fikr, 1404/1984.

İbn Hacer el-Askalânî, Takrîbü̈t-Tehzîb, nşr. M. Avvâme, Halep: Dârü’r-Reşîd, 1408/1988.

İbn Hibbân, es-Sikāt, I-IX, Haydarâbâd: Dâiretü'l-maârifi'l-Osmâniyye, 1398/1978.

İbn Hibbân, Kitâbü'l-Mecrûhîn, nşr. Mahmûd İbrâhim Zâyed, I-III, Beyrut: Dârü'l-ma'rife, $1412 / 1992$.

İbn Hibbân, Sahîhu İbn Hibbân bi-tertîbi İbn Balabân, nşr. Şuayb el-Arnaût, I-XVIII, Beyrut: Müessesetür-risâle, 1414/1993.

İbn Kuteybe, el-Maârif, nşr. Servet Ukkâşe, Kahire: Dârü’l-maârif, 1401/1981.

İbn Mâce, es-Sünen, nşr. Halîl Me’mûn Şîha, I-III, Beyrut: Dârü’l-márife, 1416/1996.

İbn Sa'd, et-Tabakātü’l-kübrâ, nşr. İhsan Abbas, I-VIII, Beyrut: Dâru Sâdır, 1387/1968.

İbn Şâhin, Fezâilü Fâtıma, nşr. Ebû İshak el-Huveynî, Cîze: Mektebetü’l-tev'iyyeti'lİslâmiyye, 1427/2007.

İbn Şehrâşûb, Menâkıbü âli Ebî Tâlib, I-IV, Beyrut: Dârü'l-edvâ, 1412/1991.

İbnü'l-Mibred, Bahrü'd-dem fî men tekelleme fîhi'l-İmâm Ahmed bi-medh ev zem, nşr. Ebû Usâme Vasiyyullah b. Muhammed b. Abbas, Riyad: Dârür-râye, 1409/1989.

İclî, Ebü'l-Hasan, Ma'rifetüs-sikāt, nşr. Abdülalîm Abdülazîm el-Bestevî, I-II, Medine: Mektebetü'd-dâr, 1405/1985. 
İmamoğlu, Abdullah Taha, Hadis ve Siyaset, İstanbul: Beka Yayıncılık, 2015.

Ka'bî, Kabûlü̉l-ahbâr ve ma'rifetü’r-ricâl, nşr. Ebû Amr el-Hüseynî b. Ömer b. Abdürrahîm, I-II, Beyrut: Dârü'l-kütübi'l-ilmiyye, 1421/2000.

Kohlberg, Etan, "From Imāmiyya to Isnā 'Ashariyya", Bulletin of the School of Oriental and African Studies (BSOAS), 39/3 (1996): 521-34.

Kohlberg, Etan, “An Unusual Shīī Isnād”, Israel Oriental Studies (IOS), 5 (1975): 142-49.

Kûfî, Ebüll-Kāsım Furât b. İbrâhim, Tefsîr, nşr. Muhammed el-Kâzım, Tahran: Vizâret-i Ferheng ve İrşâd-i İslâmî, 1374/1416.

Kuzudişli, Bekir, Şîa ve Hadis: Başlangıcından Kütüb-i Erbaa'ya Hadis Rivayeti ve İsnad, İstanbul: Klasik, 2017.

Kuzudişli, Bekir, "Sunnī-Shīī Interaction in the Early Period -The Transition of the Chains of Ahl al-Sunna to the Shìa-", Ilahiyat Studies: A Journal on Islamic and Religious Studies, 6/1 (2015): 7-45.

Küleynî, Usûlüll-Kâfî, nşr. M. Ca‘fer Şemseddin, Beyrut: Dârü’t-teârüf li’l-matbûât, $1411 / 1990$.

Meclisî, M. Bâkır, Bihârüll-envâri'l-câmia li-düreri ahbâri'l-eimmeti'l-athâr, I-CX, Beyrut: Müessesetü'l-vefâ, 1403/1983.

Müfîd, Şeyh, el-İhtisâs, nşr. Ali Ekber el-Gaffârî, Beyrut: Müessesetü’l-A 'lemî li’l-matbûât, $1430 / 2009$.

Müfîd, Şeyh, el-Emâlî, nşr. Ali Ekber el-Gaffârî, Beyrut: Dârü’t-teyyâri'l-cedîd, ts.

Müslim b. Haccâc, el-Câmiu's-sahîh, I-III, İstanbul: Çağrı Yayınları, 1412/1992.

Necâşî, Ahmed b. Ali, er-Ricâl, Beyrut: Şeriketü'l-A 'lemî li’l-matbûât, 1431/2010.

Nesâî, ed-Duafầ ve’l-metrûkîn, nşr. Bûrân ed-Dannâvî - Kemâl Yûsuf el-Hût, Beyrut: Müessesetü'l-kütübi’s-sekāfiyye, 1405/1985.

Nesâ̂, es-Sünenüll-kübrâ, nşr. Abdülgaffâr Süleyman el-Bündârî - Seyyid Kesrevî Hasan, I-VI, Beyrut: Dârü'l-kütübi'l-ilmiyye, 1411/1991.

Nesâî, el-Müctebâ el-ma'rûf bis'Süneni’s-sugrâ, I-IX, Kahire: Dârü’t-te’sîl, 1432/2012.

Nu'mânî, İbn Ebû Zeyneb Muhammed b. İbrâhim, el-Gaybe, nşr. Fâris Hassûn Kerîm, y.y.: Dâru'l-Cevâdeyn, 1432/2011.

Özdirek, Recep - Ali Hakan Çavuşoğlu, “Süfyân es-Sevrî”, DİA, 2010, XXXVIII, 23-28.

Sandıkçı, Kemal, “İbn Ukde”, DİA, 1999, XX, 427-28.

Şehristânî, el-Milel ve’n-nihal, nşr. M. Seyyid Kîlânî, I-II, Beyrut: Dârü'l-ma'rife, 1395/1975.

Taberânî, el-Mu'cemüll-evsat, nşr. Târık b. Ivazullah - Abdülmuhsin el-Hüseynî, I-X, Kahire: Dârü'l-Harameyn, 1415/1995.

Tahâvî, Şerhu müşkili’-âsâr, nşr. Şuayb el-Arnaût, I-XV, Beyrut: Müessesetü’r-risâle, $1431 / 2012$.

Tirmizî, el-Câmiu's-sahîh, nşr. Ahmed M. Şâkir, I-V, Kahire: Mustafa el-Bâbî el-Halebî, $1394 / 1975$.

Tokpınar, Mirza, “Abdurrazzak B. Hemmam (126-211/744 827)'in Şiilikle İtham Edilmesi Üzerine Bir İnceleme”, Dinî Araştırmalar, 3/9 (2001): 77-92; 4/10 (2001): 71-88. 
Tûsî, Ebû Ca'fer, el-Fihrist, nşr. M. Sâdık Âl-i Bahrülulûm, Necef: el-Mektebetü’l-Murtazâ, ts.

Tûsî, Ebû Ca'fer, el-Gaybe, nşr. İbâdullah et-Tahrânî - Ali Ahmed Nâsih, Kum: y.y., 1411.

Tûsî, Ebû Ca'fer, el-Emâlî, nşr. Behrâd el-Ca'ferî - Ali Ekber el-Gaffârî, Tahran: Dârü’lkütübi'l-İslâmiyye, 1381 hş./2002.

Tûsî, Ebû Ca'fer, Ricâlü’t-Tûsî, nşr. Cevâd el-Kayyûmî el-İsfehânî, Kum: Müessesetü’nneşri'l-İslâmî, ts.

Tüsterî, M. Takī, Kāmûsürr-ricâl, I-XII, Kum: Müessesetün-neşri'l-İslâmî, ts.

Ukaylî, ed-Duafâül-kebîr, nşr. Abdülmu'tî Emîn Kal'acî, I-V, Beyrut: Dârü'l-kütübi'lilmiyye, $1404 / 1984$.

el-Usûlüs-sitte aşer, nşr. Ziyâeddin el-Mahmûdî, Kum: Dârü'l-hadîs li't-tıba ve’n-neşr, $1381 / 1423$.

Yahyâ b. Maîn, et-Târîh (Dârimî), nşr. Ahmed M. Nurseyf, Dımaşk: Dârü’l-Me’mûn li’ttürâs, 1400.

Yahyâ b. Maîn, et-Târîh (Dûrî), Yahyâ b. Maîn ve kitâbühü̈t-Târîh içinde, nşr. Ahmed M. Nurseyf, I-IV, Mekke: Merkezü'l-bahsi'l-ilmî ve ihyâi't-türâsi'l-İslâmî, 1399/1979.

Yahyâ b. Maîn, Suâlât: Rivâyetü İbni'l-Cüneyd / Suâlâtü İbni'l-Cüneyd li-Yahyâ b. Maîn, Mevsûatü Târîhi İbn Maîn içinde, nşr. Muhammed es-Seyyid Osman, I-II, Beyrut: Dârüll-kütübi'l-ilmiyye, 1432/2011, II, 270-372.

Zehebî, el-Kâşif fî ma'rifeti men lehû rivâye fi'l-Kütübiss-sitte, nşr. İzzet Ali Îd Atıyye - Mûsâ Muhammed Ali, I-III, Kahire: Dârü'l-kütübi'l-hadîse, 1392/1972.

Zehebî, Mîzânüll-i'tidâl fî nakdir-ricâl, nşr. M. Rıdvân el-Araksûsî, I-V, Beyrut: erRisâletü'l-âlemiyye, 1430/2009.

Zehebî, Siyeru a 'lâmi’n-nübelâ', nşr. Şuayb el-Arnaût v.dğr., I-XXX, Beyrut: Müessesetü’rrisâle, $1432 / 2011$. 


\section{A New Look at Sunnī-Shī'īte Sectarianism: Reinvented Contexts of Prophetic Traditions}

The separation of the Shìite community from the mainstream Sunnis is not solely relevant to the process of a sect's identity-creation and systematization. Rather, this separation also influenced the study of hadith during the second/eighth century. Throughout the second century, hadith transmitters from the group of Ahl al-hadith (People of tradition) and those from the Shìite tradition participated within the same scholarly circles and attended classes taught by the same scholars. However, by the end of the second century and the beginning of the third century, Shīite students were only able to continue their studies in Shīite circles. Certain scholar-leaders, such as Jafar al-Șādiq and Mūsā al-Kāẓim, contributed significantly to the identity creation of the community. During this process of separation, critics from Ahl al-hadìth reviewed the Shìite-inclined transmitters in an increasingly negative tone. Further, every group that fell outside of the mainstream Muslim community participated, in one way or another, in fabricating traditions in order to legitimize their own positions. In addition to fabrications, alterations in contexts and alternative interpretations emerged in this period. Particularly, certain alterations occurred to the contexts of the transmissions by the Shìite-inclined transmitters from Ahl al-hadìth circles to Shìite circles. Although this article includes discussions on Sunnī-Shīite narrative transitivity, it aims in particular to identify alterations to contexts during narrative transmissions or later stages.

It seems that reinvention or alteration to the contexts of prophetic traditions played a significant role in influencing sectarian principles, even if they cannot be compared with fabrications or ungrounded interpretations. When one examines in detail the traditions under the headings of virtues or defects, "reinvention of contexts" or "alterations of contexts" occur in three notable ways: 1- A tradition from a Sunnī source is transmitted to a Sunnī source or more generally to a Shīite source with completely different background information; 2- A lengthy tradition in a Sunnī source is transmitted partially to a Shīite source and that part is placed beside multiple transmission of the same narrative; 3- A tradition from both Sunnī and Shīite sources is transmitted with a new meaning and loses its original sense, thereby supporting the sectarian position.

Identifying the period in which context alterations occurred and the actors responsible for the alterations is important to tracing Sunni-Shīite narrative transitivity. This article examines several traditions that exist in the sources of both schools and enable us to trace transitivity. It analyzes the traditions on "Hypocrite's grudge and Muslim's love", "I am warrior" and "Alîs gate" as examples of reinvented or altered contexts; and the traditions of "Twelve caliphs" and "May God make you proud" as examples of semantic shifts in meanings. Narrative transitivity and context alterations primarily occurred from the end of the second century and the beginning of the third century until the first half of the fourth century. This argument corroborates many parallel studies. Almost all of the individuals who were responsible from the narrative transitivity and context alterations were identified as transmitters from Küfa who were accused of being Shīite-inclined scholars. 
While identifying these transmitters, studying the chains of transmissions in alternative sources seems to be as useful as analyzing the texts of the traditions. In fact, some traditions are recorded in Shìite sources with Sunnì chains of transmission until a specific generation, but then the names in the chains diverge from those that are found in Sunnī biographical dictionaries. Particularly, starting in the beginning of the third century, the proportion of Shīite-inclined scholars in Sunnī chains decreases and Shīìte transmitters are mostly recorded in Shīite biographical dictionaries. This is related to the fact that the transmitter, before whom are Sunnī authorities and after whom are Shīites, can be held responsible for a particular hadìth's transition into Shìite sources and its context alterations. One should take into consideration both the transmitter's Shìite inclinations and the forms of recording by Shìite scholars in order to identify responsibility for the context alterations in the second century.

Context alterations and changes to the texts of traditions seem to match up with Shiite thought in this period. In fact, it is noteworthy that at a time before the theory of twelve imams was solidified, the tradition of "twelve caliphs" is not recorded in Shìite sources. Similarly, in narrative transitivies during the second century, praises of Alī and the Prophet's family as well as statements targeting his opponents could take more emphasized forms and some political implications might be added to the traditions. However, certain themes, such as chastity and return, which had a role in institutionalized Shīism were not included during this period. The investigation of changes in transmissions from this point of view can improve our understanding of the development of Imāmī Shīism.

The history of the early Sunnī tradition can only be understood by examining in detail the development of other sects/schools and their relations to the Sunni community, because no religious school can be examined in isolation. This method seems to be difficult for certain schools such as Mu'tazila and Murjia, but it fits well in terms of a parallel reading of Shīìte and Sunnī sources, because both have considerable scholarly accumulation. This kind of study will also enable us to understand dark spots in the activity of jarh-ta'dil and the composition of books during the second and third centuries.

Keywords: Sunnī, Shīìte, context, Alī, tradition. 